\title{
Xanthine Scaffold: Available Synthesis Routes to Deliver Diversity by Derivatization
}

\author{
Rita Petrucci ${ }^{1, *}$, Marta Feroci $^{1}$, Leonardo Mattiello ${ }^{1}$ and Isabella Chiarotto ${ }^{1, *}$ \\ ${ }^{I}$ Dept. Basic and Applied Sciences for Engineering (SBAI), Sapienza University of Rome, via del Castro Laurenziano, 7 , \\ 00161, Rome, Italy
}

A R T I C L E H IS T O RY

Received: January 23,2020

Revised: February 27,2020

Accepted: March 10, 2020

DOI:

10.2174/1570193X17999200507103141

\begin{abstract}
The functionalization of the skeletal systems of heterocycles represents a significant goal for the development of new compounds. The heterocyclic molecule xanthine (3,7-dihydro- $1 \mathrm{H}$ purine-2,6-dione) is a purine base with a bicyclic ring skeleton and four different nitrogen atoms, three of them are -NH groups. The principal derivatives are the well known natural methylxanthines (e.g., caffeine, theophylline and theobromine) that have prominent physiological effects at a very low dose. The natural methylated xanthines, theophylline, theobromine and caffeine, are present in different plants such as the tea, cocoa and coffee species. For this reason natural xanthines can be considered as bio-based and renewable starting materials; their use in organic synthesis is strongly recommended in order to carry out sustainable chemistry. Essentially, the xanthine scaffold led to the preparation of numerous compounds very attractive in the pharmaceutical field, and these drugs are commercialized for a wide range of biological activities. The scope of this mini-review is to consider the use of natural xanthines as starting material in chemical transformations carried out in organic solvents, without the intent to be exhaustive of all the synthetically chemical applications. More information on the chemical and electrochemical reactivity of this structural core in an organic solvent can be useful for the scientific community. The effectiveness of natural xanthines can be improved by modifying the structures of these already biologically active compounds.
\end{abstract}

Keywords: Bio-based, chemical transformations, derivatives, electrochemical transformations, natural methylated xanthines, NHC complexes, xanthines.

\section{INTRODUCTION}

The research of new procedures via manipulation of functional groups around fundamental skeletal systems is an important goal of synthetic heterocyclic chemistry. The development of new compounds by derivatization of xanthine scaffolds has withdrawn more interest thanks to their activity in biological systems and their contribution to the new medicinal drug discovery. Xanthine (3,7-dihydro- $1 H$-purine2,6-dione, Fig. 1) is a purine base, mainly produced by the body tissues and found in humans' fluids, and by botanical species [1]. Xanthine has a bicyclic ring skeleton, and the rings are referred to as A- (uracil) and B- (imidazole) rings, respectively. Xanthine decomposes by heating without melting and with partial sublimation; it is poorly soluble in water and even less in alcohol, whilst it is soluble in mineral acids and freely soluble in basic solutions. Xanthine has four different nitrogen atoms; consequently, it gives typical reactions of the corresponding functional groups.

*Address correspondence to these authors at the Dept. Basic and Applied Sciences for Engineering (SBAI), Sapienza University of Rome, via del Castro Laurenziano, 7, 00161, Rome, Italy;

E-mails: isabella.chiarotto@uniroma1.it; rita.petrucci@uniroma1.it
Among purine-based compounds, xanthine and its derivatives have attracted great interest, as they provide important medicinal effects [2]. The natural methylaxanthines, theophylline, theobromine and caffeine (Fig. 2) exhibit biological activity as stimulants, and thus they have been used for pharmacological purposes [3-5].

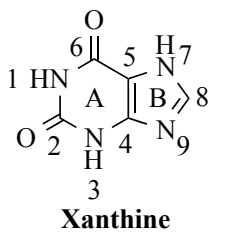

Fig. (1). The basic scaffold of xanthine.<smiles>[Y4][CH][C@H](C)n1c(=O)[nH]c(=O)c2c1ncn2C</smiles>

Fig. (2). Xanthine and its natural methylated derivatives: caffeine, theobromine and theophylline. 


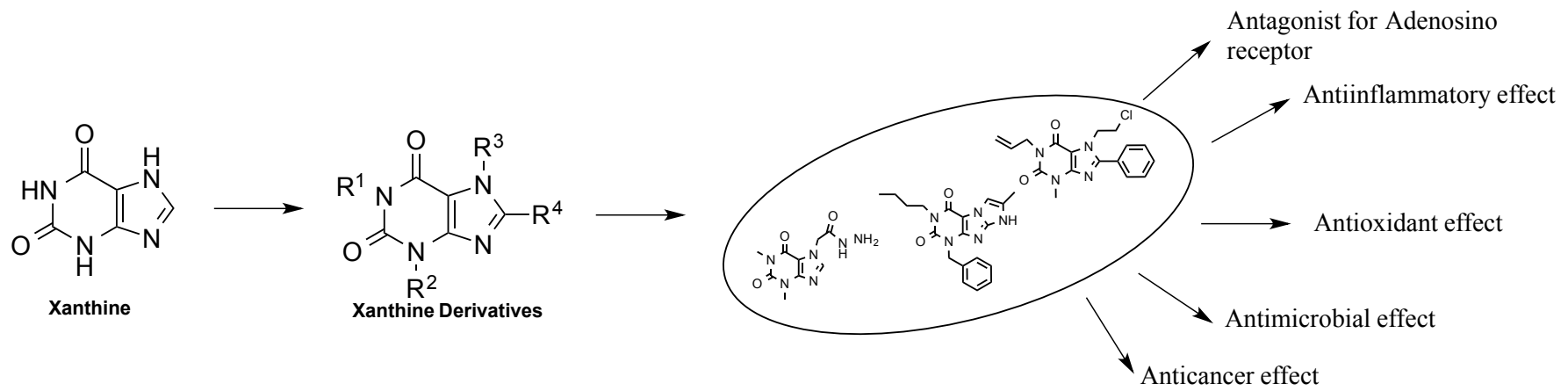

Fig. (3). Xanthine as a lead molecule for future drugs for several therapeutic targets.

The recent development of new xanthine derivatives for different diseases proves the importance of the xanthine core for medicinal chemistry research. Various natural, semisynthetic and synthetic derivatives have been synthesized and evaluated for various therapeutic activities, including bronchodilators, cognitive enhancers or nootropic drugs, and as anti-inflammatory activity [6]. Since the majority of metabolic diseases could derive from oxidative stress, it is significant that recent studies have shown the positive effect of xanthines on diseases related to oxidative stress [7-9].

Xanthine and its derivatives can be used as starting materials for the synthesis of derivatives with different functional groups at different positions of the scaffold. In order to explore diverse roles of xanthine derivatives, the investigation of various methods for their synthesis and structural modification of their structures has now become an important goal of several research groups.

The activities of xanthines are linked to the diversity of substituents that can be introduced, especially at the $\mathrm{N}^{1}, \mathrm{~N}^{3}$, $\mathrm{N}^{7}$ and $\mathrm{C}^{8}$ positions (Fig. 1). We will consider both classical chemical transformations and electrochemical ones. Among the chemical transformations, organic electrochemistry is considered an eco-friendly technique, as the reagent is the electron, non-pollutant, with no by-products and precise stoichiometric control $[10,11]$.

We will report the chemical reactions in which natural xanthines act as starting material, in order to obtain functionalized compounds. The covered reactions will fall mainly in the following categories of xanthine derivatives:

- Xanthine-Annelated

- Xanthine-NHC complexes

- Functionalization at $\mathrm{N}^{1}, \mathrm{~N}^{3}, \mathrm{~N}^{7}$ and $\mathrm{C}^{8}$

- 7-Substituted Xanthines

- 8-Substituted Xanthines

- 7,8-Substituted Xanthines

- Xanthines Electrochemistry

\section{XANTHINE DERIVATIVES AND PHARMACEU- TICAL APPLICATIONS}

Xanthine derivatives have gained great interest because of their dietary effects and their large presence in natural and non-natural products. In fact, their detection and quantification are topics of great importance due to their widespread presence also in beverages and wastewaters [12]. The availability of xanthines from natural sources involves a series of opportunities. The scope of this mini-review is not to provide a complete report on the activities of biological derivatives of xanthine, but we here report only some of these activities. Different natural and synthetic xanthine derivatives have been recognized as therapeutically potent compounds and utilized for targeting various diseases such as bronchodilator for the treatment of asthma [13, 14], enzyme regulators of cell signaling pathways [15], phosphodiesterase inhibitors [16], adenosine antagonists [17], histone deacetylase activators [18], antimicrobials [19], etc.

Moreover, the antioxidant and anti-inflammatory activities of xanthine derivatives have been largely reported [20$22]$. The presence of reactive oxygen species and nitric oxide (NO) derivatives in the cell produces undesirable effects on its components, such as carbohydrates, proteins, lipids, and nucleic acids. These processes can have a significant role in a nonspecific pathogenesis mechanism for different disease states, such as atherosclerosis, ischemic stroke, and diabetes. Therefore, antioxidant compounds development able to stop the pathological biochemical processes at different levels of oxidative and nitrosative stress is a challenge for medical and pharmaceutical sciences [23].

Chemical synthesis represents an important way to obtain structural diversity of compounds of interest. Xanthines can act as a starting material for large-scale diversification in derivatization reactions. The presence of many sites $\left(\mathrm{N}^{1}, \mathrm{~N}^{3}\right.$, $\mathrm{N}^{7}, \mathrm{~N}^{9}$ and $\mathrm{C}^{8}$ sites) for chemical substitution represents an important characteristic of this scaffold (Fig. 3). Moreover, the molecular and physiological behavior of xanthines represents a further research challenge [24].

\section{XANTHINE-ANNELATED}

The construction of a third ring starting from the bicyclic xanthine structure can lead to the production of biologically valuable compounds and many physico-chemical characteristics can be modulated in this way. As an example, Müller and coworkers synthesized imidazo[2,1-i]purinones and ring-enlarged analogs derived from xanthine derivatives in the development of novel adenosine $\mathrm{A}_{2 \mathrm{~A}}$ and $\mathrm{A}_{3 \mathrm{~A}}$ receptor antagonists, which showed a greater water solubility [25]. The tricyclic purine derivatives have been obtained accord- 


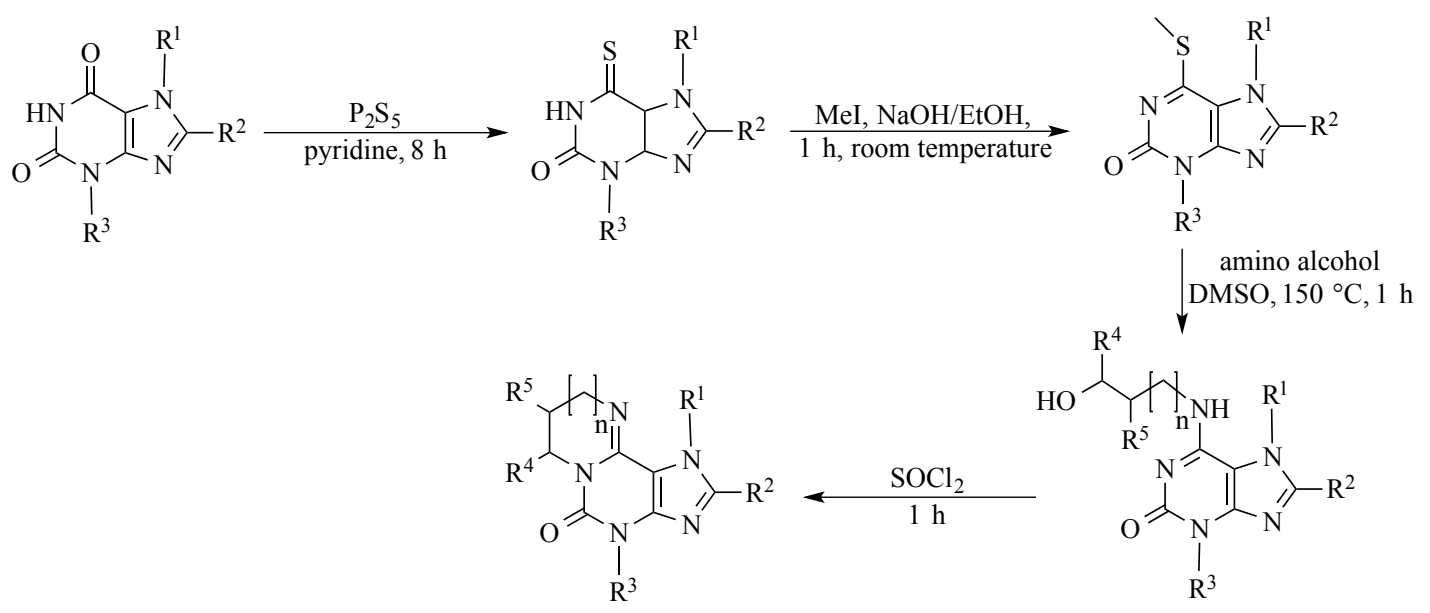

Scheme 1. Synthesis of imidazo[2,1-i]purinone derivatives and ring-enlarged analogs [26].

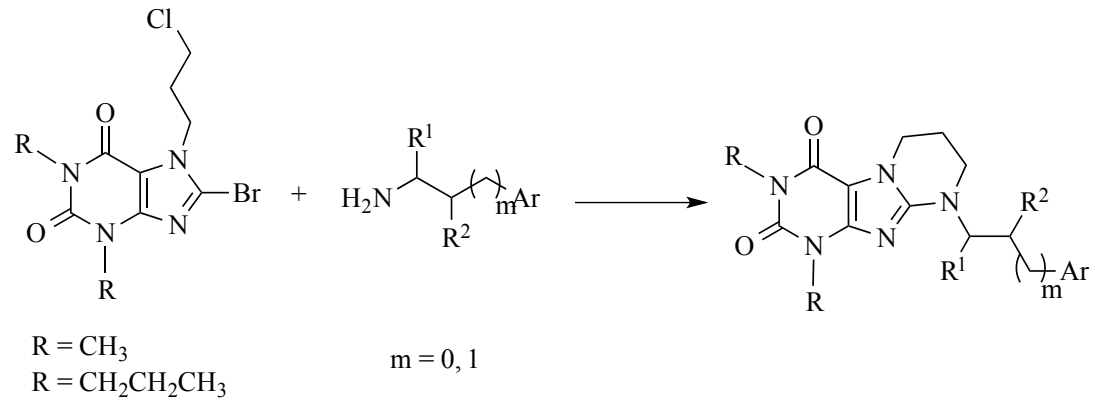

Scheme 2. $N$-phenethyl-substituted pyrimido[2,1-f]purinediones and analogues $[27,28]$.

ing to the route described by Shimada et al. [26], reported in Scheme 1. Thionation with phosphorus pentasulfide was the first step and it was carried out in dry pyridine to yield 6thioxanthines. In the second step, the amino-substituted purines were obtained after methylation with methyl iodide. The obtained compounds were treated with amino alcohols in dimethyl sulfoxide (DMSO). The final ring closure was performed by cyclization with thionyl chloride at high temperature (under reflux conditions) to obtain the tricyclic purine derivatives. The yields for cyclization of unbranched hydroxy-alkyl derivatives depend on the ring size of the final product. The synthesis of five and six rings proceeds in high yields (Scheme $\mathbf{1}$ ).

The construction of a third ring can also involve the imidazole ring, as reported by Drabczyńska and coworkers in the continuous search for novel adenosine $\mathrm{A}_{2 \mathrm{~A}}$ receptor antagonists $[27,28]$. The synthetic route is reported in Scheme 2. In particular, 7-(3-chloropropyl)-8-bromotheophylline and 7-(3-chloropropyl)-8-bromo-1,3-dipropylxanthine were used and then cyclized with phenylalkylamines to obtain $\mathrm{N}$ phenethyl-substituted pyrimido[2,1-f]purinediones (Scheme 2). The $N$-phenethyl-substituted pyrimido[2,1-f]purinediones and analogs with the modifications of ethylene spacer showed micromolar or sub-micromolar affinity as adenosine $\mathrm{A}_{2 \mathrm{~A}}$ receptor antagonists and the affinity depends on the kind of substituent on the aromatic ring. More recently, similar compounds were synthesized by the same procedure and tested for analgesic activity as well as for adenosine receptor binding affinity [29].
Another contribution to the previous studies is based on the annelation of xanthine derivatives to give new imidazo[2,1-f]purine-2,4-diones and pyrrolo[2,1-f]purine-2,4diones. The new compounds resulted in the most potent and selective human $\mathrm{A}_{3}$ adenosine receptor antagonists [30]. The strategy employed involved an intermolecular Wittig reaction between the carbonyl moiety of the introduced $\mathrm{N}^{7}$-chain and the bromomethyl function at the 8-position, in order to obtain the cyclization of the pyrrole ring condensed at the $\mathrm{N}^{7}-\mathrm{C}^{8}$ link of the purinone nucleus. In particular, the derivative 1-benzyl-7-methyl-3-propyl-1 $H, 8 H$-imidazo[2,1-f]purine-2, 4-dione (Fig. 4) showed an excellent affinity toward the human $A_{3}$ adenosine receptor and a significant selectivity versus the other subtypes [31].

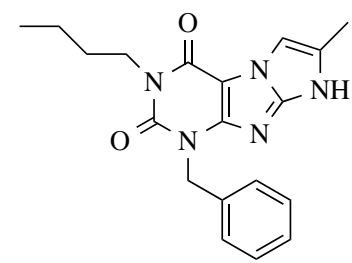

Fig. (4). 1-Benzyl-7-methyl-3-propyl-1 $H, 8 H$-imidazo[2,1-f]purine2,4-dione [31].

Moreover, Drabczyńska et al. reported a series of new cycloalkyl derivatives of imidazo-, pyrimido- and 1,3diazepino[2,1-f]purinediones tested for adenosine receptor affinity. In this paper, the syntheses and other chemical properties of these of $\mathrm{N}$-cycloalkyl-substituted imidazo-, 
pyrimido- and 1,3-diazepino[2,1- $f$ p purinediones were described [32]. These compounds were synthesized by cyclization of 7-halogenoalkyl-8-bromo-1,3-dimethyl xanthine derivatives with aminocycloalkanes (Scheme 3). The basic nitrogen atom in the cycloalkyl substituted tricyclic xanthine derivatives gives a better water-solubility in comparison to the other xanthine derivatives as well as non-xanthine adenosine receptor antagonists.

The synthesis of 1,3-dimethylperhydroimidazo-, -pyrimidoand -1,3-diazepino[2,1-f]purinediones with cycloalkyl substituents in the $\mathrm{N}^{8}, \mathrm{~N}^{9}$ or $\mathrm{N}^{10}$ position, respectively, of the annelated ring was then implemented. The starting materials were obtained according to described procedures [33].<smiles>Cn1c(=O)c2c(nc(Br)n2C)n(C)c1=O</smiles>

$\mathrm{n}=2,3,4$ $\mathrm{X}=\mathrm{Cl}, \mathrm{Br}$

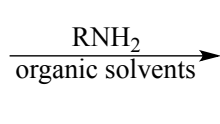

$\mathrm{R}=$ cycloalkyl, alkylcycloalkyl
Scheme 3. Synthesis of imidazo-, pyrimido- and 1,3-diazepino[2,1$f$ ]purinediones [27-33].

These compounds were obtained by cyclization with amines under different reaction conditions (amount of amine, various organic solvents and different reaction times). The class of tricyclic compounds containing the third ring is considered as bioisosteric analogs of $(E)$-8-styrylxanthine [27, $33,34]$ having potential antiparkinsonian $[28,33]$, and anticonvulsant activities [35].

A new class of interesting MAO-B inhibitors derived from1,3-dimethylsubstituted tetrahydropyrimido[2,1-f]purinediones were obtained by ring-closing reactions to yield tetrahydropyrimidine[2,1-f]purinediones starting from 8-bromo-7-(3-chloropropyl)-1,3-dialkyl xanthines. In the general procedure the synthesis was carried out under heating in a microwave reactor [36].

More recently, a new series of 1,3-dipropyl- and 1,3dibutylpyrimido[2,1-f]purinedione-9-ethylphenoxy derivatives, including a $\mathrm{CH}_{2} \mathrm{CONH}$ linker between the $\left(\mathrm{CH}_{2}\right)_{2}$ amino group and the phenoxy moiety, were analyzed as $\mathrm{A}_{1} / \mathrm{A}_{2 \mathrm{~A}}$ adenosine receptor antagonists. The synthesis was carried out in the absence of solvent and by microwave- assisted heating to link the amide moieties with the pyrimido[2,1-f]purinedione-9-ethylphenoxy scaffold (Fig. 5) [37].

The solvent-free microwave-assisted synthetic protocol was used to insert the amide fragment into the $N^{9}$ phenylethylpyrimido[2,1-f]purinedione core, obtained by the previously described methods [32, 34].

The same authors published a paper where a series of novel compounds was synthesized and evaluated as MAO-B inhibitors. A typical modification of the tricyclic structures based on a xanthine core by enlargement of the third heterocyclic ring or attachment of various substituted benzyl moieties was carried out to develop a new compound, the 9-(2chloro-6-fluorobenzyl)-1,3-dimethyl-6,7,8,9-tetrahydropyri-
mido[2,1-f]purine-2,4(1H,3H)-dione, tested as a dual-target drug for neurodegenerative diseases [17]. The synthesis scheme is very similar, but in the last step of synthesis the non-traditional scheme was used (solvent-free microwaveassisted).
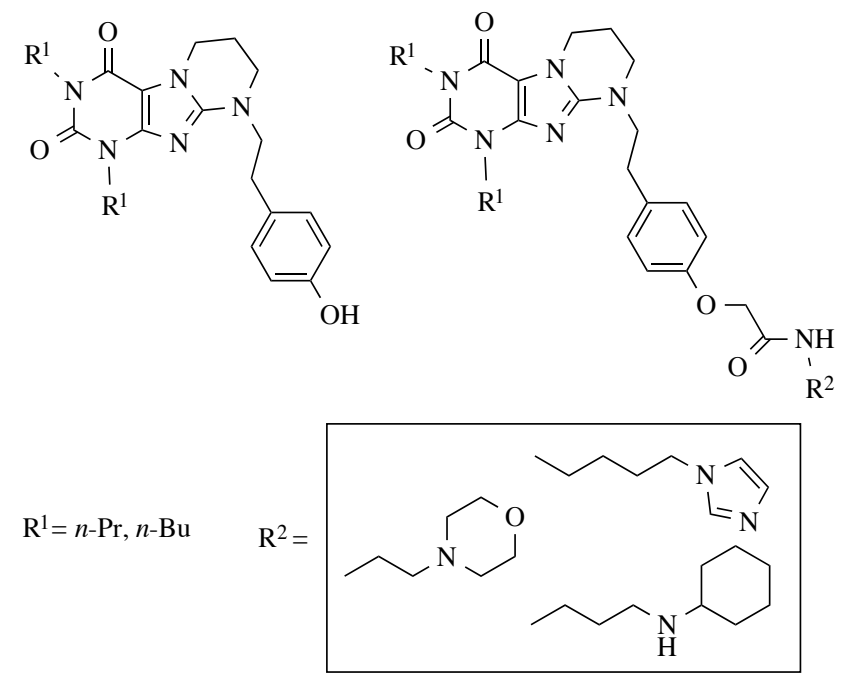

Fig. (5). Tetrahydropyrimido[2,1-f]purinedione scaffold and derivatives.

\section{XANTHINE-NHC COMPLEXES}

$\mathrm{N}-H$ terocyclic carbenes (NHCs) are non-charged molecules containing a divalent carbon atom in a nitrogencontaining ring [38]. They are frequently used as organocatalysts in organic synthesis [39-40], or as ligands in organometallic compounds [41]. As the xanthine structure contains an imidazole ring (possible NHC precursor), N-heterocyclic carbene (NHC) complexes derived from xanthines have aroused much attention. Xanthine-NHC complexes can be used as catalysts [42-43] for different important organic transformations or as drugs (antimicrobial or anticancer agents). As an example, Hor and co-workers reported the synthesis and the properties of $\mathrm{Pt}(\mathrm{II})$ xanthine-NHC derivatives [44].

Xanthines can be easily functionalized and their metal derivatives result in optimal candidates for the research of novel metallo-drugs. In fact, the combination of biological activity with a metal centre in the same chemical structure can produce compounds with pharmaceutical applications. Therefore, the good reactivity of xanthines core along with their biological activity makes the metal derivatives excellent candidates for the development of novel metallodrugs. Moreover, depending on the kind of metal, several xanthineNHC complexes are excellent catalysts for important organic reactions [45].

In order to obtain an NHC from the xanthine scaffold, its $\mathrm{N}$-alkylation to yield an imidazolium salt is necessary. Generally xanthines are functionalized before the preparation of their corresponding azolium salt. The synthesis of xanthineNHC metal complexes generally involves coordination strategies carried out with transmetalation agents and bases able to deprotonate the N-heterocyclic azolium salt [46]. 
<smiles>Cn1c(=O)[nH]c2c(ncn2C)c1=O</smiles>

1) KHMDS, DMF, 15 min., RT

2) $[\mathrm{Au}(\mathrm{tht}) \mathrm{Cl}]$, DMF, $1 \mathrm{~h}, \mathrm{RT}$

1) $0.8 \mathrm{Ag}_{2} \mathrm{O}, \mathrm{MS}, \mathrm{MeCN}$

RT, 6 h, dark

2) $[\mathrm{Au}(\mathrm{tht}) \mathrm{Cl}], \mathrm{KI}, \mathrm{MS}, \mathrm{MeCN}$

RT, overnight, dark
$\overbrace{\mathrm{H}}^{\mathrm{N}_{\mathrm{N}}^{\mathrm{O}}} \overbrace{\mathrm{N}}^{\mathrm{O}}>\mathrm{Au}-\mathrm{I}$

[AuI(MC)]

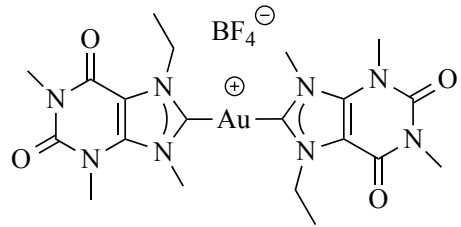

Scheme 4. Syntheses of the caffeine- and theophylline-based NHC Au(I) complexes.

Recently, starting from caffeine, theophylline and theobromine, a new class of silver(I)-N-heterocyclic carbenes was synthesized [47, 48], showing anticancer activity. For the synthesis of silver-based compounds transmetalation agents were used, such as silver oxide or acetate. As an example, the silver-NHC complexes shown in Fig. (6) were synthesized in methanol as solvent starting from the corresponding imidazolium salts and silver acetate.<smiles></smiles>

$$
\begin{aligned}
& \mathrm{R}=\mathrm{Me}, \mathrm{R}^{1}=\mathrm{Me} \\
& \mathrm{R}=\mathrm{Bn}, \mathrm{R}^{1}=\mathrm{Me} \\
& \mathrm{R}=n \mathrm{Bu}, \mathrm{R}^{1}=\mathrm{Me} \\
& \mathrm{R}=\mathrm{Ph}, \mathrm{R}^{1}=\mathrm{Me} \\
& \mathrm{R}=\mathrm{Me}, \mathrm{R}^{1}=\left(\mathrm{CH}_{2}\right)_{2} \mathrm{OH}
\end{aligned}
$$

Fig. (6). Silver-NHC complexes.

Moreover, the efficacy of a silver-caffeine NHC derivative has been observed in two specific airway infection protocols [49].

Over the last years, gold(I)-N-heterocyclic carbenes (NHCs) have been transformed into some of the most popular cores in medicinal inorganic chemistry [50]. Several authors have described the promising anticancer activities of gold(I)-NHC complexes in vitro and also in vivo. A new series of gold(I)-N-heterocyclic carbene (NHC) complexes based on xanthine ligands have been synthesized and characterized [51]. A neutral compound $\mathrm{Au}(\mathrm{I})$-methylated caffeine2-yliene $[\mathrm{AuI}(\mathrm{MC})]$ was synthesized adapting a procedure described by Berners-Price et al. [52]. This simple procedure is reported in Scheme 4. Different cationic complexes were obtained via the commonly used silver-carbene route by reacting caffeinium and theophyllinium tetrafluoroborates with silver oxide and then with chloro(tetrahydrothiophene)gold(I) [Au(tht)Cl] [53-54]. This bis-carbene complex [Au(caffein2-ylidene $\left.)_{2}\right]\left[\mathrm{BF}_{4}\right]$ (Scheme 4) appeared to be selective for human ovarian cancer cell lines and poorly toxic against healthy organs.

Platinum-based drugs such as cisplatin were pivotal in the fight against cancer. NHC-Pt(II) complexes derived from caffeine via $\mathrm{C}^{8}$-halogen activation could be obtained starting from 8-chlorocaffeine, which reacted with $\left[\mathrm{Pt}\left(\mathrm{PPh}_{3}\right)_{4}\right]$ under oxidative addition of the $\mathrm{C}^{8}$-halogen bond to the metal center. The resulting $\mathrm{Pt}(\mathrm{II})$ complexes feature a $\mathrm{C}^{8}$-bound yli- dene ligand (Scheme 5). Protonation of ylidene at the $\mathrm{N}^{7}$ atom yielded complexes bearing a protic $\mathrm{N}$-heterocyclic carbene ligand derived from the purine base with an -NMe, NHsubstitution. The purine derivatives, such as 8-chlorocaffeine, could be converted into protic NHC ligands by an oxidative addition reaction without prior alkylation of both $\mathrm{N}$ atoms of the five-membered heterocycle [55].

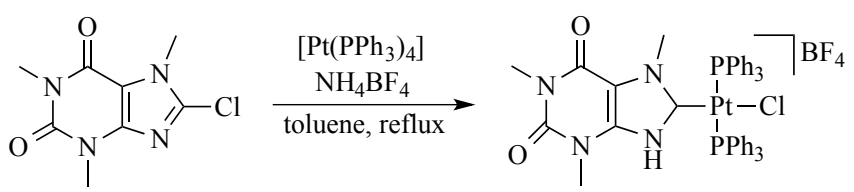

Scheme 5. Pt(II) complexes with a $C^{8}$-bound ylidene ligand [55].

An NHC-palladium compound was obtained using $\mathrm{N}^{9}$ benzylcaffeine as a starting material. The study of these salts to form the NHC-Pd complexes has shown interesting behavior. For the 1,3,7-trimethyl-9-benzyl xanthine, the use of a strong base was possible to deprotonate $\mathrm{C}^{8}$, since the only acidic proton in the ligand is $\mathrm{H}^{8}$. Trans-dichloro-bis $(1,3,7$ trimethyl-9-benzylxanthine-8-ylidene) palladium(II) was obtained starting from 1,3,7-trimethyl-9-benzylxanthinium bromide in tetrahydrofuran solvent in the presence of potassium tert-butoxide (Scheme 6). After completing the reaction, potassium bromide was eliminated from the mixture by filtration. The $\mathrm{PdCl}_{2}(\mathrm{NCPh})_{2}$ was dissolved in acetonitrile and the solution was slowly added to the free carbene to obtain the Pd(II) metallo-complex [56].

Copper catalysts are often employed in organometallic chemistry. Copper is also an important element in the biological processes. New generations of NHC copper catalysts have been recently studied. In particular, copper(I) complexes bearing NHC ligands have been reported as active catalysts for different transformations including cyclo-additions and homo- and hetero-coupling reactions [57]. With the aim to enhance the water solubility, novel copper complexes were synthesized by the use of theophylline as a basic scaffold to prepare copper catalytic system more water-soluble. The water-soluble quaternary ammonium salt $N$-(4-(bromomethyl)benzyl)- $N, N$-dimethylethanammonium bromide was linked to the theophylline using $\mathrm{K}_{2} \mathrm{CO}_{3}$ in DMF.

The resulting product was methylated with methyl iodide in $\mathrm{CH}_{3} \mathrm{CN}$ at $80^{\circ} \mathrm{C}$ to give the water-soluble $\mathrm{NHC}$ salt. 


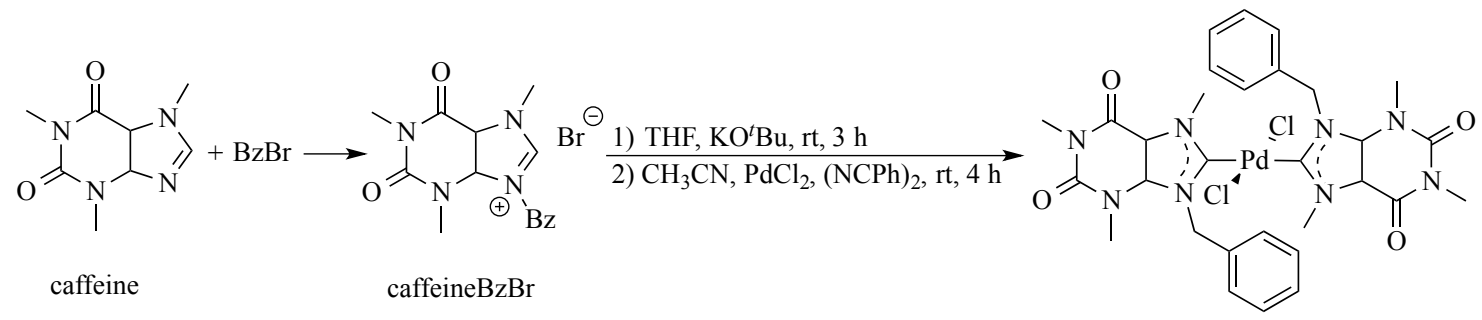

$\mathrm{PdCl}_{2}(\mathrm{CaffBz})_{2}$

Scheme 6. Syntheses of $\mathrm{PdCl}_{2}(\mathrm{CaffBz})_{2}$ via carbene starting from caffeineBzBr [56].

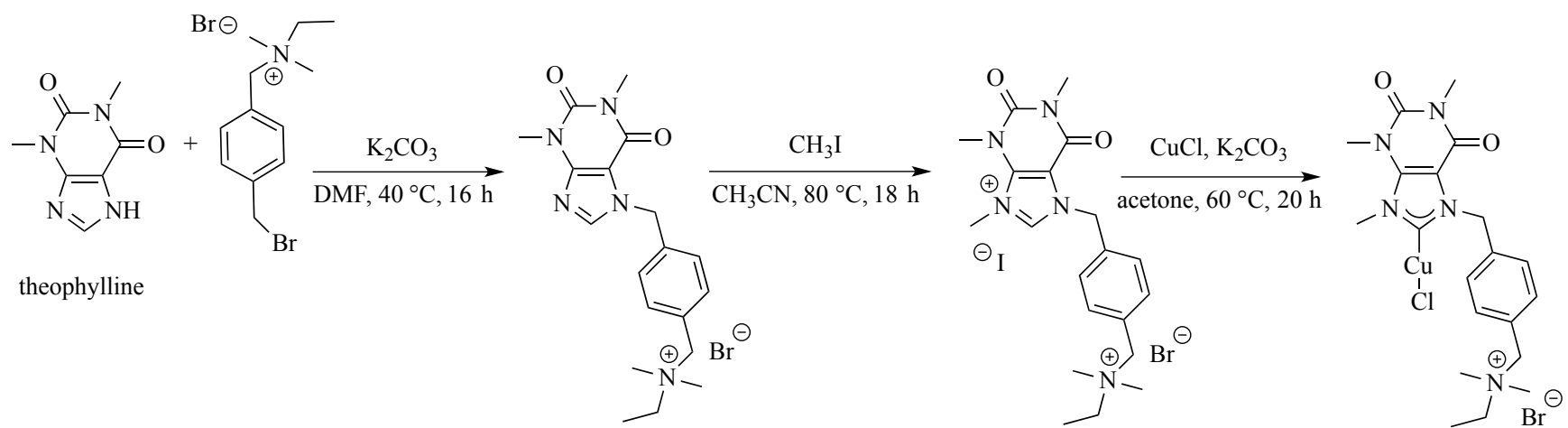

Scheme 7. Synthesis of the water-soluble copper complex used as a catalyst starting from theophylline as active catalysts for different transformations including cyclo-additions and homo- and hetero-coupling reactions [57].

Treatment of the NHC salt with copper(I) chloride and an excess of potassium carbonate in dry acetone under reflux conditions gave the copper complex (Scheme 7). In order to examine the activity assay of the theophylline copper complex, two different reactions were selected and tested: a three-component click reaction and the Glaser homocoupling reaction. The copper complex catalyst displayed excellent activity in these reactions [57].

\section{FUNCTIONALIZATION AT $\mathbf{N}^{1}, \mathbf{N}^{3}, \mathbf{N}^{7}$ AND $\mathrm{C}^{8}$}

Xanthines can act as starting materials for large-scale structural diversifications by derivatization reactions. In the xanthine scaffold there are the $\mathrm{N}^{1}, \mathrm{~N}^{3}, \mathrm{~N}^{7}, \mathrm{~N}^{9}$ and $\mathrm{C}^{8}$ sites available for the substitution. The most challenging part of the xanthine based drug development process is the presence of three -NH groups. In combinatorial drug development processes, a definite understanding of the relative reactivity of the different -NH functions of xanthine has been fundamental to optimize the results.

The principal -NH groups derivatives are the well known natural methylxanthines (e.g. caffeine, theophylline and theobromine). Despite being very interesting as promising pharmacophores, there are few methods for 1- and 1,3substituted xanthines synthesis.

The classic Traube purine synthesis from 6-aminouracil derivatives [58, 59] and its recent modifications [60-64] require long reaction times and harsh reaction conditions. Moreover, these syntheses are typically indicated for the preparation of alkyl-substituted xanthines. Other different reported methods to substitute xanthines employed isocyanates in a two-step cyclocondensation reaction [65-67] or 4- amino-5-carbamoylimidazoles and phosgene [68]. A new and practical method for the synthesis of 1- and 1,3-substituted xanthines, which avoids the use of toxic reagents, has been reported by Zavialov, et al. A base-promoted condensation of the imidazole with carbamates led to a 1-substituted 7PMB xanthine followed by alkylation to give the final product according to Scheme 8 [69].<smiles></smiles>

Scheme 8. Synthesis of 1- and 1,3-substituted xanthines $P M B=p$ methoxybenzyl group [69].

Therefore, it is not surprising that N-alkylation of xanthines is still actively studied and most of the derivatives are related to sites $\mathrm{N}^{1}, \mathrm{~N}^{3}, \mathrm{~N}^{7}$. About the $\mathrm{C}^{8}$ derivatives, Shamim et al. reported the synthesis and the effects of 8-phenyl and 8 -cycloalkyl substituents on the activity of theophylline, caffeine, 1,3-dipropylxanthine, 1,3-dipropyl-7-methylxanthin 3propylxanthine, and 1-propylxanthine [70]. Caffeine and theophylline are unselective adenosine receptor antagonists. The structural modification of the xanthine scaffold, espe- 


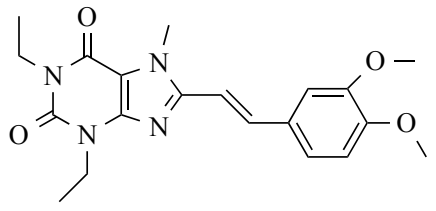

Istradefylline

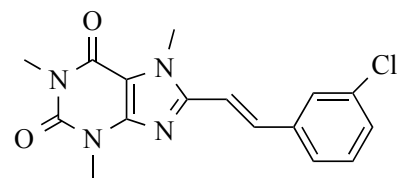

8-chlorostyrylcaffeine (CSC)

Fig. (7). Structures of xanthine derivatives istradefylline and 8-chlorostyrylcaffeine (CSC) [17].

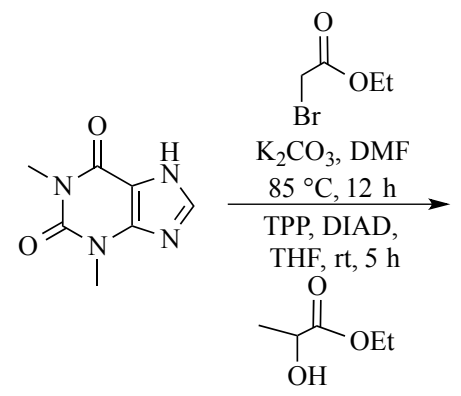

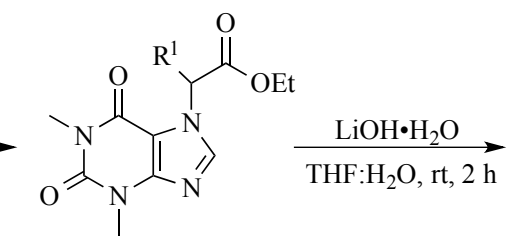<smiles>[R]C(C(=O)O)n1cnc2c1c(=O)n(C)c(=O)n2C</smiles><smiles>COC(=O)C(N)Cl</smiles><smiles>[R]C(NC(=O)C([R])n1cnc2c1c(=O)n(C)c(=O)n2C)C(=O)OCC#C</smiles><smiles>[R]C(NC(=O)C([R])n1cnc2c1c(=O)n(C)c(=O)n2C)C(=O)O</smiles>

$\mathrm{O}$<smiles>Cn1c(=O)c2[nH]cnc2n(C)c1=O</smiles>

Scheme 9. Synthesis of theophylline containing acetylene compounds.

cially in position $\mathrm{C} 8$, induced the discovery of a class of derivatives as active compounds: the 8-styrylxanthines. Among this group of derivatives, the istradefylline and 8-chlorostyrylcaffeine (CSC) appear to have important pharmacological activities (Fig. 7) [17].

Below the most recent and interesting reactions are reviewed concerning the $\mathrm{N}^{1}, \mathrm{~N}^{3}, \mathrm{~N}^{7}$ and $\mathrm{C}^{8}$ funzionalizations organized as mono-, di- e tri- substituted xanthines.

\subsection{7-Substituted Xanthines}

In order to develop a new target-specific anticancer from the theophylline structure, a series of novel theophyllinecontaining acetylenes and 1,2,3-triazoles with different nucleoside derivatives have been synthesized. There are two synthetic routes to obtain N7-alkylated compounds. For the series of theophylline-containing acetylene derivatives, the commercially available theophylline was alkylated with ethyl 2-bromoacetate in dimethylformamide and potassium carbonate, or with ethyl 2-hydroxypropanoate by using the reagents tetrapropylammonium perruthenate (TPP) and diisopropylazodicarboxylate (DIAD) to give the ester compounds. A series of steps and the subsequent reactions with propargyl alcohol using $N, N$-dicyclohexylcarbodiimide and 4-dimethylaminopyridine gave theophylline derivatives containing a terminal acetylene group (Scheme 9).

Lastly, the reaction of acetylene compounds with sodium ascorbate and $\mathrm{CuSO}_{4} \times 5 \mathrm{H}_{2} \mathrm{O}$ with the corresponding azide compound in a mixture of ethanol and water $(2: 1)$, led to the synthesis of theophylline containing 1,2,3-triazole nucleoside derivative. These compounds were examined for anticancer and antimicrobial activity [71].

The thiazolidine-4-one was used as a scaffold to synthesize new xanthine derivatives with better antioxidant effects in comparison to theophylline [72]. The new 1,3-thiazolidine4-one derivatives were synthesized according to Scheme $\mathbf{1 0}$. Theophylline (1,3-dimethylxanthine), in the presence of sodium methoxide, gave the salt in a quantitative yield, which was in turn reacted with ethyl chloroacetate and resulted in theophylline-ethyl ester. Theophylline hydrazide was obtained in good yield in the following reaction in the presence of an excess of hydrazine hydrate. Then, the condensation of the compound with different aromatic aldehydes produced the corresponding hydrazones in satisfying yields [73]. Finally, the cyclization of hydrazones in the presence of mercaptoacetic acid led to thiazolidine-4-one derivatives in moderate to excellent yields.

Two new xanthine derivatives with the thiazolidine-4-one scaffold (Fig. 8), and in particular their chitosan-based formulations, previously reported having promising antidiabetic effects, have been evaluated regarding a possible protective effect on the liver and renal functions as well as on haematological main problems under diabetes mellitus conditions [74].

\subsection{8-Substituted Xanthines}

8-Bromocaffeine (8-BC) is a commercially available compound that can be used in nucleophilic aromatic substitution 

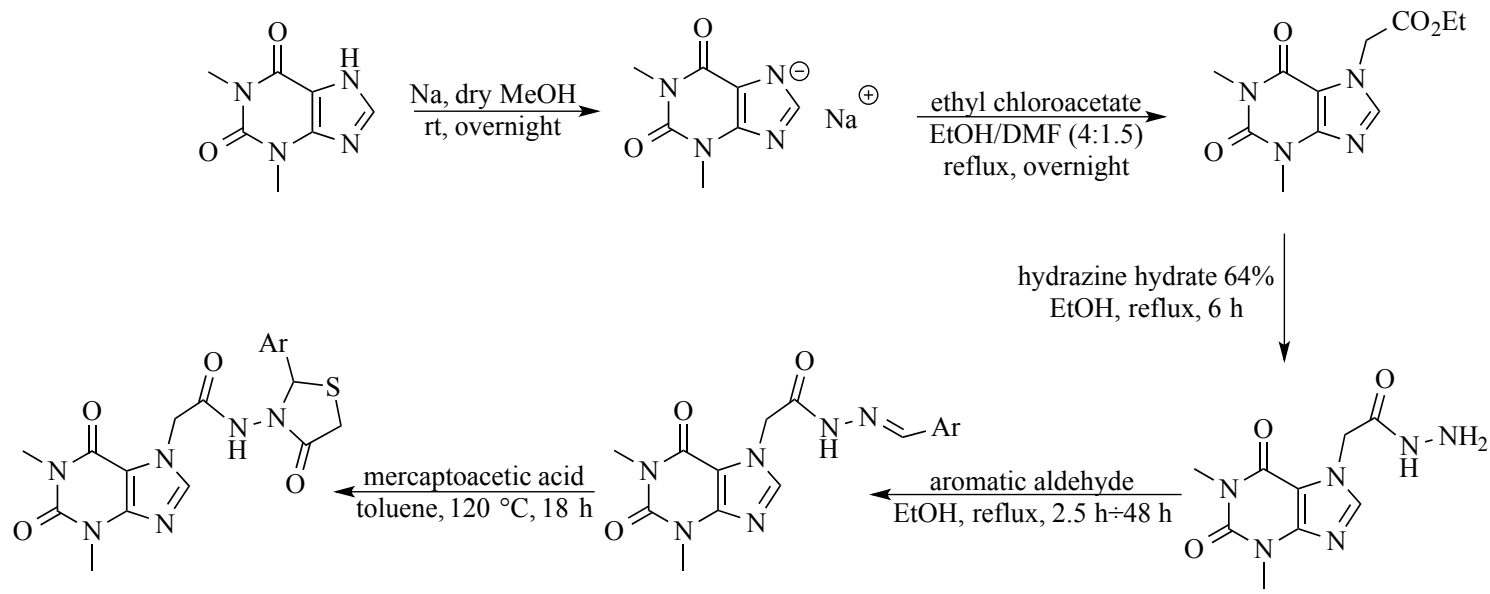

Scheme 10. Synthesis of theophyllinyl-acetamido-thiazolidin-4-one derivatives. Reagents and conditions: (a) sodium, dry MeOH, r.t., overnight; (b) ethyl chloroacetate, EtOH/DMF (4:1.5), reflux, overnight; (c) hydrazine hydrate 64\%, EtOH, reflux, 6 h; (d) aromatic aldehyde, $\mathrm{EtOH}$, reflux, $2 \mathrm{~h} 30 \mathrm{~min}-48 \mathrm{~h}$; (e) mercaptoacetic acid, toluene, heating $120^{\circ} \mathrm{C}, 18 \mathrm{~h} \mathrm{[72].}$
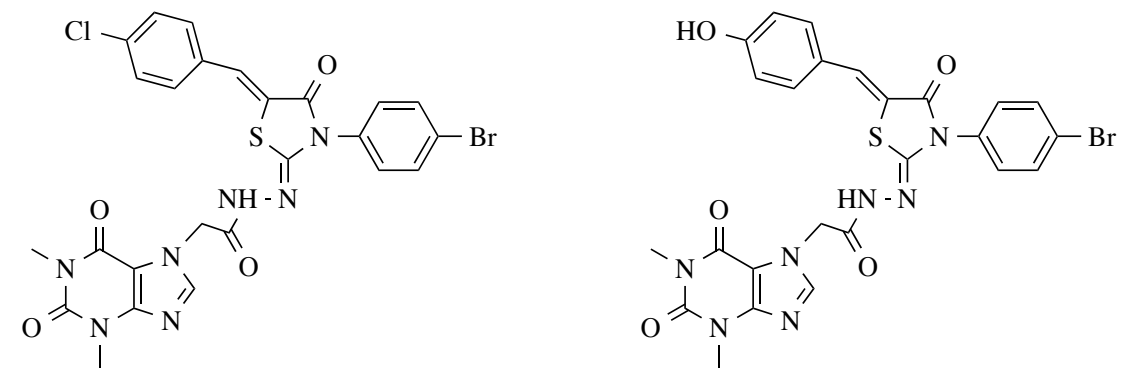

Fig. (8). The structure of the xanthine-thiazolidine derivatives.

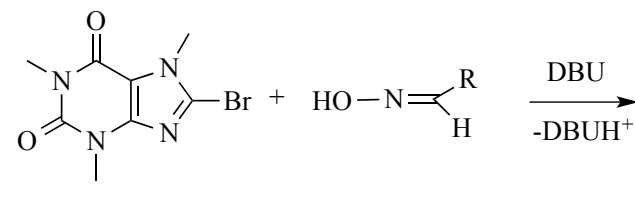<smiles>[R]C#N</smiles>

Scheme 11. A supposed mechanism for the conversion of aldoximes into nitriles using 8-BC [75].<smiles>[R]n1c(=O)c2c(ncn2[R])n([R])c1=O</smiles><smiles>[R]c1ccc2cccc([X])c2c1</smiles><smiles>[R]c1ccccc1[X]c1nc2c(c(=O)n([R])c(=O)n2[R])n1[R]</smiles>

Scheme 12. 8-Heteroaryl-substituted xanthines synthesis.

reactions. Moreover, 8 -BC is an important precursor for many drug syntheses and also employed as a reagent in organic chemistry. Soltani Rad and coworkers described the application of 8-BC as a reagent in organic chemistry [75]. In this case, the synthesis of nitriles was rapid, convenient and it could be obtained starting from aldoximes using DBU in DMF solvent in the presence of 8-bromocaffeine. This method was operative for the conversion of aliphatic and aromatic aldoximes into nitriles using a microwave or conventional heating conditions (Scheme 11).

8-Heteroaryl-substituted xanthines are highly potent antagonists at human $\mathrm{A}_{2 \mathrm{~B}}$ adenosine receptors. The interest in the direct $\mathrm{C}$-arylation of xanthines led to the study of a catalytic system that was proved to be efficient in the oxidative cross-coupling with a variety of thiophenes or furans (Scheme 12) [76].

The catalytic system comprises $\mathrm{Pd}(\mathrm{OAc})_{2}$ as a catalyst, $\mathrm{Cu}(\mathrm{OAc})_{2} \cdot \mathrm{H}_{2} \mathrm{O}$ as an oxidant, pyridine, and 1,4-dioxane (Scheme 12). A variety of thiophenes and furans were tested with caffeine, $n$-butyl theophylline, benzylic theophylline, benzylic theobromine, and 1,3-diethyl xanthine. The resulting unsymmetrical bi-heteroaryl molecules were obtained in good to excellent yields [76].

8-Vinylxanthines are well-known antagonists for the human $\mathrm{A}_{2 \mathrm{~A}}$ adenosine receptors [77]. They can be efficiently obtained using a bimetallic $\mathrm{Pd} / \mathrm{Cu}$ catalyst, which results in an efficient and versatile system for the dehydrogenative Heck coupling of xanthines with alkenes to give the corre- 


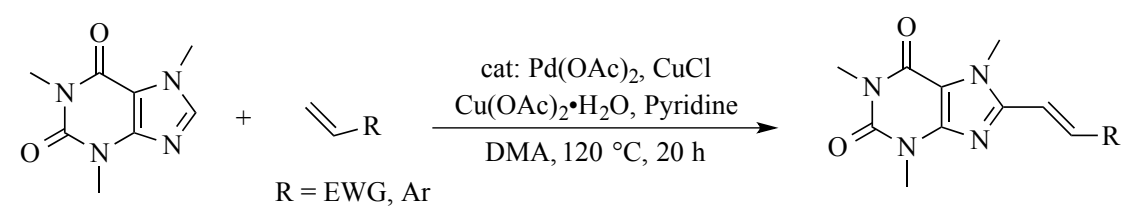

Scheme 13. $\mathrm{Pd} / \mathrm{Cu}$-catalyzed dehydrogenative alkenylation of caffeine with alkene.

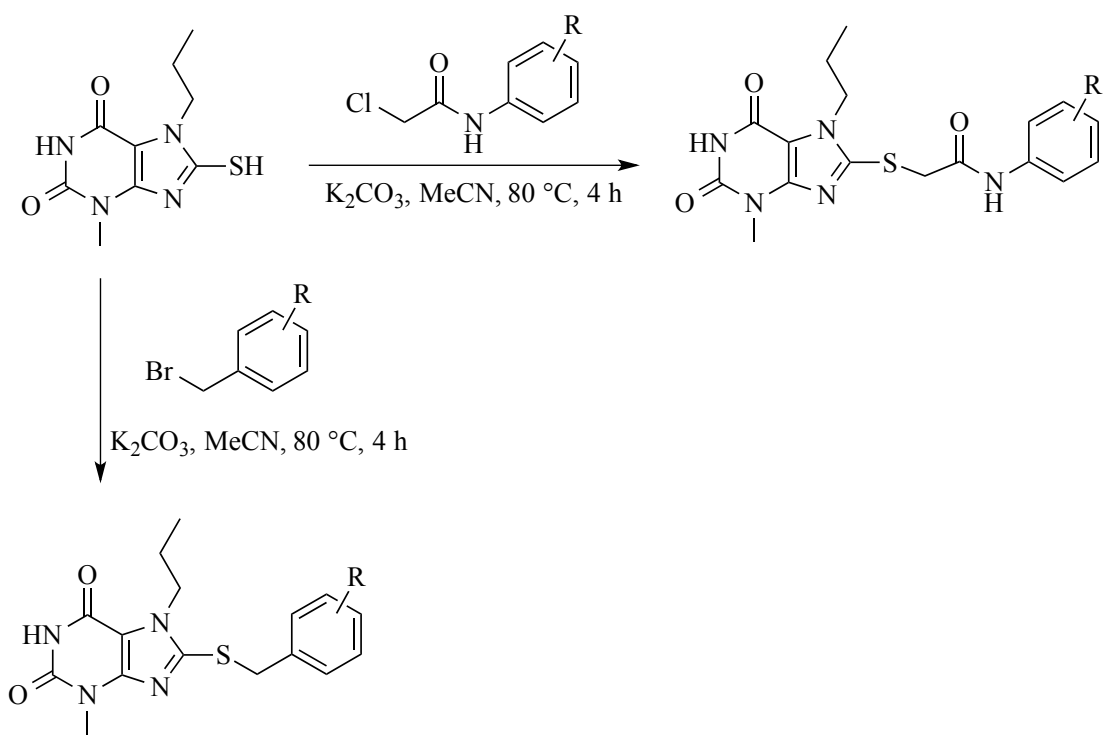

Scheme 14. Synthesis of the key intermediate 8-mercapto-3-methyl-7-propyl-3,7-dihydro- $1 H$-purine-2,6-dione.

sponding 8-alkenylated products in satisfactory yields. In order to obtain 8-alkenylated xanthine derivatives, the optimized reaction conditions were selected studying the reactivity of caffeine with $n$-butyl acrylate. After screening a number of parameters, it was found that all the components had a crucial role. The best result was achieved when the reaction was performed in the presence of $\mathrm{Pd}(\mathrm{OAc})_{2}(2.5 \mathrm{~mol} \%)$, $\mathrm{CuCl}(15 \mathrm{~mol} \%), \mathrm{Cu}(\mathrm{OAc})_{2} \mathrm{xH}_{2} \mathrm{O}$ (1.5 equiv.) and pyridine (1.0 equiv.) in dimethylacetamide at $120^{\circ} \mathrm{C}$ for $20 \mathrm{~h}$. Under the optimized reaction conditions, a relatively broad series of olefins was proved. Activated alkenes such as $\alpha, \beta$ unsaturated esters and amides smoothly resulted more reactive in the coupling with caffeine to give the corresponding alkenylated products. This protocol was useful to prepare other xanthines derivatives such as 8-alkenylated theophylline and theobromine (Scheme 13). Through this procedure, the transformation of the alkaloid scaffolds into fluorescent molecules was possible. The derivatives p-extended conjugated N-heteroarenes showed notable fluorescent properties and have resulted to be potential reagents for biological imaging applications [78].

A very recent paper reported the ligand-based design of fragment-like xanthine derivatives as LSD1 (Histone lysinespecific demethylase 1) inhibitors. The FAD-based drug strategy was used to design and synthesize xanthine derivatives. The compounds obtained by modification at position 8 of the xanthine scaffold were synthesized as shown in Scheme 14.

The key intermediate, the 8-mercapto-3-methyl-7-propyl3,7-dihydro- $1 H$-purine-2,6-dione, was next used to synthe- size a focused library of xanthine derivatives through varying substituents. A base promoted nucleophilic substitution reaction was also used for the introduction of two types of common substituents (benzyl and acetamidyl) to position 1 of the xanthine scaffold [79].

\subsection{7,8-Substituted Xanthines}

An efficient and versatile synthetic approach was described to design fluorescent kinase inhibitors derived from the xanthine scaffolds. To facilitate the exploration of $\mathrm{N}^{7}$ and $\mathrm{C}^{8}$-substituents, theophylline was identified as a convenient starting point. The fluorescent kinase inhibitors based on the xanthine scaffold were obtained by using a two steps synthetic route. Thus, the strategy toward the target compounds was obtained with a versatile combination of regioselective $\mathrm{N}^{7}$-arylation and/or direct $\mathrm{C}^{8}$-arylation. Various organic solvents were used in the first step to obtain the $\mathrm{N}^{7}$ aryl xanthine derivatives. The synthesis of a variety 7,8diaryl-1,3-dimethyl-1H-purine-2,6(3H,7H)-diones was accomplished by the $\mathrm{C}^{8}$-arylation of aryl xanthines with arylbromides bearing functional groups such as acetamide, sulfonamide, and carbamate groups. The building of the $\mathrm{C}^{8}$ (hetero)aryl ring was obtained by the copper catalyzed C-H bond activation. The reaction (Scheme 15) which was carried out in the presence of $\mathrm{Pd}(\mathrm{OAc})_{2}, \mathrm{Cu}(\mathrm{I})$, and $\mathrm{Cs}_{2} \mathrm{CO}_{3}$, gave compounds in satisfactory to good yields [80].

\section{XANTHINES ELECTROCHEMISTRY}

The electrochemical methodology features as a valuable ally in the organic synthesis and it often allows obtaining 

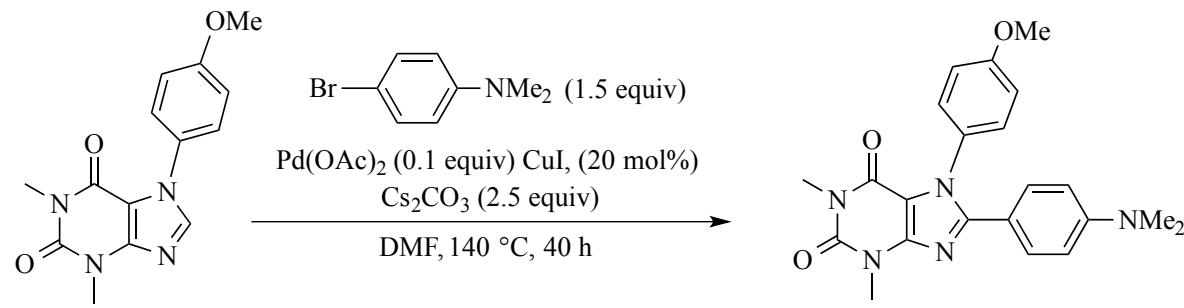

$78 \%$

Scheme 15. Coupling of $N^{7}$-aryl-teophylline with 4-bromo- $N, N$-dimethylaniline [80].

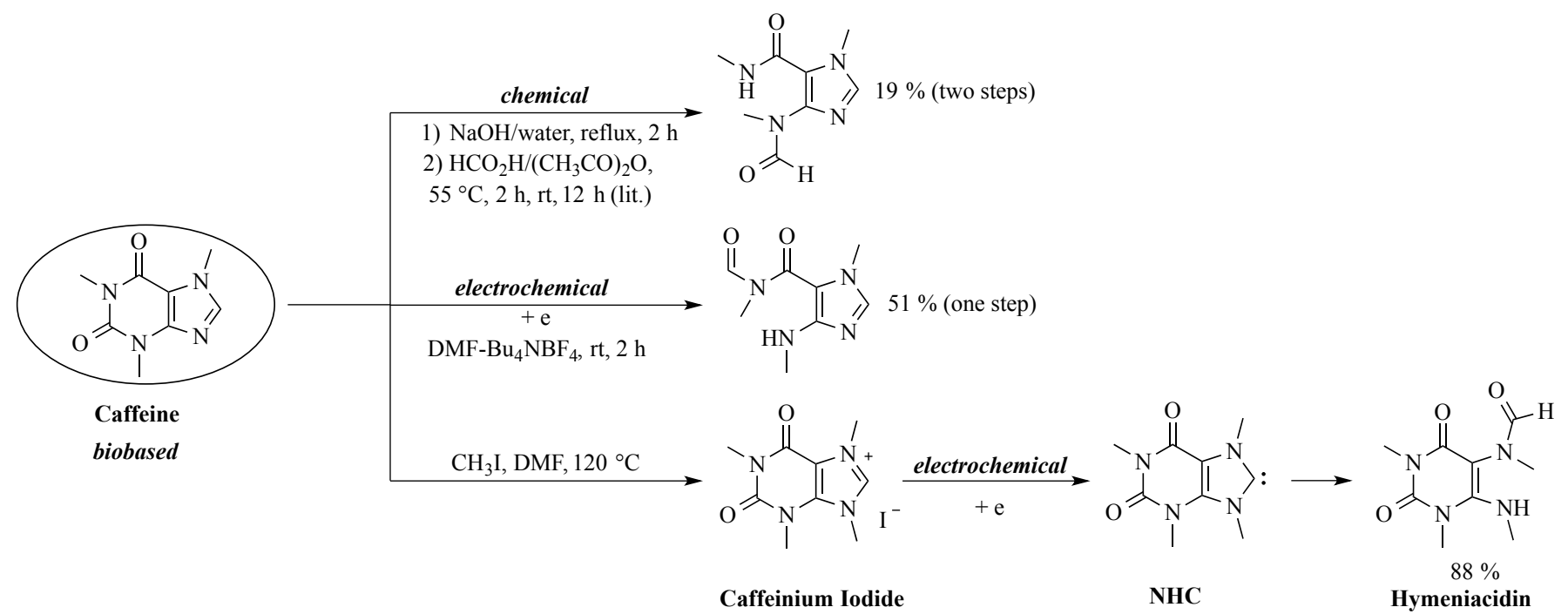

Scheme 16. Different synthetic strategies for caffeine transformation: chemical $v$ s. electrochemical.

products, which are not obtainable (or with difficulty) using classical chemical reactions. Despite the electrochemical methodology provides reactions both in oxidation and in reduction, the large number of papers present in the literature on xanthine electrochemistry is on the electrochemical oxidation.

As we have described earlier for xanthine-NHC complexes, the literature mainly reports the use of caffeine as starting material for the synthesis of the corresponding $\mathrm{NHC}$ ( $N$-heterocyclic carbene) metal complexes, after its transformation into the corresponding caffeinium salt and deprotonation at the $C^{2}$ atom of the imidazolium ring $[56,51]$. Nonetheless, a few papers report the use of caffeine as a starting material in organic synthesis [81, 82].

In a recent paper the electrochemical reduction of caffeine was studied [83]. The caffeine cathodic reduction, in DMF-Bu $\mathrm{NBF}_{4}$, yielded $N$-formyl- $N, 1$-dimethyl-4-(methylamino)-1H-imidazole-5-carboxamide, a highly functionalized imidazole product derived from the opening of the uracil ring. This reactivity is opposite to the cathodic one of the methylated salt of caffeine, which yields the opening of the imidazole ring and formation of substituted uracil (hymeniacidin), derived from the hydrolysis of the corresponding electrogenerated N-heterocyclic carbene (Scheme 16) [84]. Moreover, the products obtained by cathodic reduction of caffeine, or its salt, are different from what can be obtained by classical organic synthesis. The cathodic reduction of caffeine led to the uracil ring opening with the formation of a formylated product at the amide nitrogen atom, while the classical chemical way led to the formylated product at the more basic amine nitrogen atom. Thus, the cathodic reduction yielded a product formylated at the exocyclic amide nitrogen, when a different result could be obtained by classical organic synthesis, in which the product was formylated at the exocyclic amine nitrogen. The different synthetic routes are summarized in Scheme 16. The nature of the starting material (caffeine, bio-based and thus renewable) renders these studies interesting from the "greenness" point of view.

The behavior of some naturally widespread methylxanthines under oxidative conditions has also been studied. Among these, caffeine, theophylline and theobromine are especially available in coffee, cocoa and tea, so that they have been the most largely consumed alkaloids for centuries up todays, daily taken as traditional beverages and more recently also as soft drinks, energy drinks and even as a food supplement. Many systemic effects are well known, especially those regarding the most studied caffeine; both positive and negative effects have been discussed in a recent review by Monteiro $\mathrm{J}$ et al. They have been used in traditional medicine since ancient times, as drugs in medicine for decades, and increasing pharmaceutical potentialities are emerging in the current scientific overview [85].

In particular, some beneficial effects have been in part ascribed to antioxidant properties towards damages by oxidative stress: some protective effects towards hydroxyl radical have been reported in the last twenty years by in vivo and in 


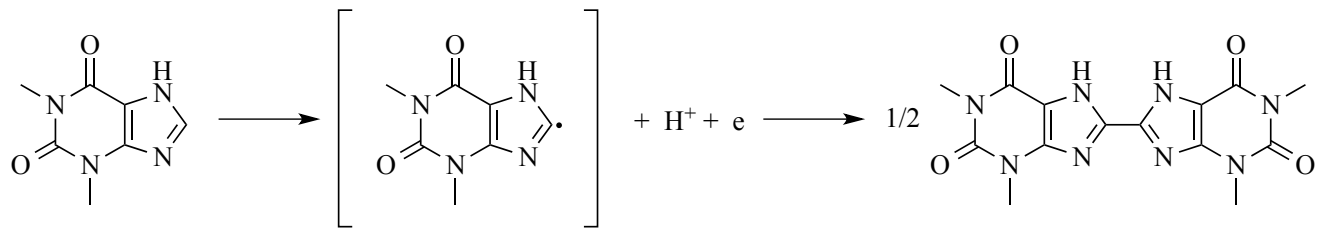

Scheme 17. Proposed mechanisms for the electrochemical oxidation of theophylline at the pyrolytic graphite electrode in $1 \mathrm{M}$ acetic acid.
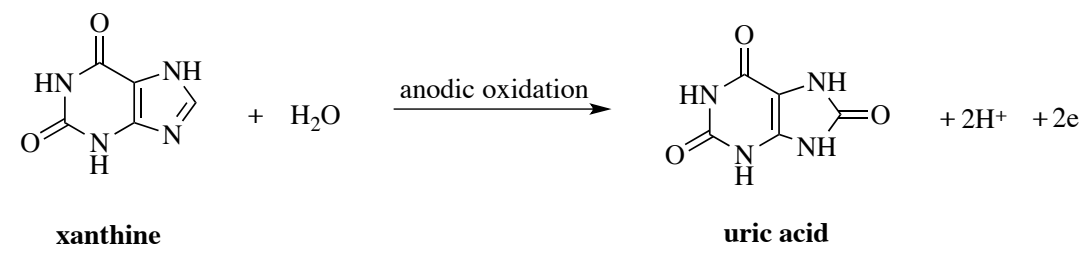

Scheme 18. Oxidation of xanthine in aqueous acetic acid.

vitro studies [86-89]. Conversely, caffeine proved inactive towards moderate hydrogen/electron scavengers as DPPH and $\mathrm{ABTS}^{+}{ }^{+}$according to Brezová V et al. 2009 [90].

There is no doubt that the potentialities of caffeine and related methylxanthines as antioxidants could have a strong impact on biomedical research. As antioxidant and antiradical activities may occur according to different mechanisms, depending on the medium, and molecular structure [91] and likely involving radical species, a deeper insight into the behavior of methylxanthines under oxidative conditions was required.

The electro-oxidation of caffeine, theophylline and theobromine in water at different $\mathrm{pH}$ on a pyrolytic graphite electrode was studied by Hansen et al., and an irreversible four electrons process was proposed. In particular, the principal and potential determining reaction for the oxidation of xanthines was proposed to start with a two-electron attack at the $-\mathrm{N}^{9}=\mathrm{C}^{8}$ - double bond to the corresponding uric acid, immediately further oxidized to an intermediate 4,5-diol species, with further different fate depending on its stability.

In the case of theophylline, a dimeric product was also observed after controlled potential electrolysis in one molar acetic acid [92-94].

More recently, the anodic oxidation of caffeine and theophylline in glacial acetic acid/sodium acetate was reported by Quintanilla et al. yielding 1,3,8-trimethyl-1,3,6,8-tetrazaspiro[4,4]nonane-2,4,7,9-tetrone and (4-acetoxy-1,3,7trimethyl-2,6,8-trioxo-9H-purin-5-yl) acetate from oxidation of caffeine and the same spiro compound 1,3,8-trimethyl1,3,6,8-tetrazaspiro[4,4]nonane-2,4,7,9-tetrone from the oxidation of theophylline. A mechanism involving the corresponding uric acid was proposed [95].

A deeper insight into the behavior of methylxanthines under oxidative conditions was carried out in an organic solvent, providing an environment more suitable to radical species and reducing chemical competing reactions than in water.

Only a few studies on the electro-oxidation of methylxanthines in organic solvent have been described. Chan et al. reported the one-electron oxidation coupled to consecutive $\mathrm{H}$ atom transfer of caffeine in acetonitrile, leading to a proto- nated caffeinium cation as the long-term product in high yield, whose structure was confirmed by single-crystal X-ray crystallography and NMR spectroscopy [96].

In recent works, Petrucci and co-workers reported a comprehensive investigation on caffeine, theophylline and theobromine in acetonitrile, including the anodic behavior by cyclic voltammetry and electrolysis in UV-vis cell, computational analysis (DFT study) and chemical reactivity with ROS (reactive oxygen species) [97]. The mono-electronic anodic oxidation of the double bond $-\mathrm{C}^{4}=\mathrm{C}^{5}$ - was proposed for both caffeine and theophylline, yielding the corresponding radical cation, quite stable in the case of caffeine ( $\mathrm{I}$ in Scheme 19), and easily deprotonating to the neutral radical in the case of theophylline (II in Scheme 19). A different reactivity for the radical cation of caffeine and the neutral radical of theophylline was then proposed, leading to different caffeine and theophylline derivatives, i.e. 4,5-disubstituted caffeine derivatives and 8-substituted theophylline derivatives (Scheme 19).

The interaction of methylxantines with superoxide and galvinoxyl as ROS was studied by UV-vis spectrophotometry, and any antiradical activity for caffeine, theophylline and theobromine was excluded. The high oxidation potential values of caffeine, theophylline and theobromine, measured in acetonitrile, and even higher in water [98], suggest that the one-electron transfer process could take place only in the presence of strong oxidants, such as $\mathrm{HO}$ radical. This led to reconsider the potential antioxidant activity of methylxanthines. The electro-oxidation of theophylline in organic solvents has also been recently reported in the literature [9], where the electrogenerated radical cation was supported by the formation of a di-hydroxy-4,5-substituted theophylline derivative, and the following deprotonated neutral radical was supported by the formation of dimeric forms in $\mathrm{C}^{8}$ (Scheme 20) as evidenced by the liquid chromatography coupled with tandem mass spectrometry analysis of the anodically electrolyzed solutions of theophylline.

\section{CONCLUSION}

This mini-review is an updated and comprehensive overview of the reaction types for derivatization of xanthine re- 

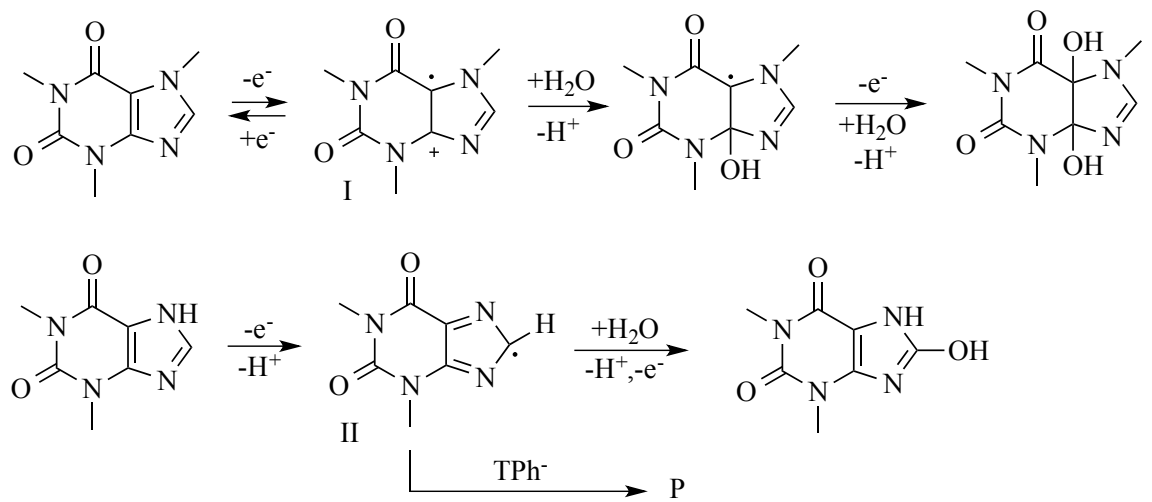

Scheme 19. Mono-electronic anodic oxidation of caffeine and theophylline in organic solvent, to the corresponding radical cation I and neutral radical II, respectively, and proposed routes to the final derivatives.<smiles>CN1C(=O)N(C)C2(O)NC=NC12O</smiles><smiles>CN1C(=O)C2N=C(c3nc4c([nH]3)c(=O)n(C)c(=O)n4C)NC2N(C)C1=O</smiles>

$$
\begin{aligned}
& \mathrm{M}=214 \mathrm{Da} \\
& {[\mathrm{M}+\mathrm{H}]^{+}=215} \\
& {[\mathrm{M}-\mathrm{H}]^{-}=213}
\end{aligned}
$$

Fragmentation

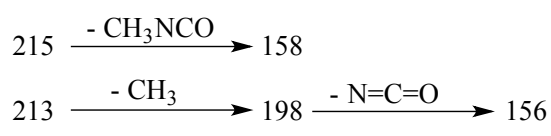

Fragmentation

$$
\begin{aligned}
& \mathrm{M}=358 \mathrm{Da} \\
& {[\mathrm{M}+\mathrm{H}]^{+}=359} \\
& {[\mathrm{M}-\mathrm{H}]^{-}=357}
\end{aligned}
$$

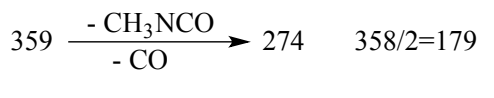

Scheme 20. The mass spectrometric data supporting the proposed structures.

ported in the literature during the last thirty years. The significant selected examples reported in this paper emphasized the possibility of utilizing the xanthine scaffold as bio-based and renewable starting material. In fact, starting from the natural products, caffeine, theophylline and theobromine, classical organic synthesis and/or biotransformations allow to obtain a wide range of products.

Chemical synthesis represents the most helpful way to obtain structural diversity of compounds employing the fragments of interest. Organic synthesis represents the means to offer a large-scale diversity in derivatization. Numerous examples show that xanthines are widely employable as biobased and renewable starting materials in organic synthesis for realizing of compounds of pharmacological interest as drugs with diverse-range biological activities. Hopefully, this mini-review can provide a source of information for organic chemists working on this structural core for the design of new selective reactions and the synthesis of new and effective drugs targeting specific human diseases.

\section{AUTHOR CONTRIBUTIONS}

All authors listed have made a substantial, direct, and intellectual contribution to the work, and approved it for publication. The schemes of this mini-review are designed by the authors on the basis of what is described in the cited articles.

\section{CONSENT FOR PUBLICATION}

Not applicable.

\section{FUNDING}

This work was supported by the Sapienza University of Rome.

\section{CONFLICT OF INTEREST}

The authors declare no conflict of interest, financial or otherwise.

\section{ACKNOWLEDGEMENTS}

Declared none.

\section{REFERENCES}

[1] Amirkia, V.; Heinrich, M. Alkaloids as drugs leads - a predictive structural and biodiversity-based analysis. Phytochem. Lett., 2014, 10, 98-103. http://dx.doi.org/10.1016/j.phytol.2014.06.015

[2] Cushnie, T.P.T.; Cushnie, B.; Lamb, A.J. Alkaloids: an overview of their antibacterial, antibiotic-enhancing and antivirulence activities. Int. J. Antimicrob. Agents, 2014, 44(5), 377-386. http://dx.doi.org/10.1016/j.ijantimicag.2014.06.001 PMID: 25130096

[3] Chrysant, S.G. The impact of coffee consumption on blood pressure, cardiovascular disease and diabetes mellitus. Expert Rev. Cardiovasc. Ther., 2017, 15(3), 151-156. 
http://dx.doi.org/10.1080/14779072.2017.1287563 PMID: 28128673

[4] Monteiro, J.P.; Alves, M.G.; Oliveira, P.F.; Silva, B.M. Structure bioactivity relationships of methylxanthines: Trying to make sense of all the promises and the drawbacks. Molecules, 2016, 21(8), 974-1006.

http://dx.doi.org/10.3390/molecules21080974 PMID: 27472311

[5] Franco, R.; Oñatibia-Astibia, A.; Martínez-Pinilla, E. Health benefits of methylxanthines in cacao and chocolate. Nutrients, 2013, 5(10), 4159-4173.

http://dx.doi.org/10.3390/nu5104159 PMID: 24145871

[6] Shanahan, P.; O’Sullivan, J.; Tipton, K.F.; Kinsella, G.K.; Ryan, B.J.; Henehan, G.T.M. Theobromine and related methylxanthines as inhibitors of Primary Amine Oxidase. J. Food Biochem., 2019, 43(2)e 12697

http://dx.doi.org/10.1111/jfbc.12697 PMID: 31353656

[7] Panusa, A.; Petrucci, R.; Lavecchia, R.; Zuorro, A. UHPLC-PDAESI-TOF/MS metabolic profiling and antioxidant capacity of arabica and robusta coffee silverskin: Antioxidants vs phytotoxins. Food Res. Int., 2017, 99(Pt 1), 155-165. http://dx.doi.org/10.1016/j.foodres.2017.05.017 PMID: 28784472

[8] Firuzi, O.; Fuksa, L.; Spadaro, C.; Bousová, I.; Riccieri, V.; Spadaro, A.; Petrucci, R.; Marrosu, G.; Saso, L. Oxidative stress parameters in different systemic rheumatic diseases. J. Pharm. Pharmacol., 2006, 58(7), 951-957.

http://dx.doi.org/10.1211/jpp.58.7.0010 PMID: 16805955

[9] Petrucci, R.; Zollo, G.; Curulli, A.; Marrosu, G. A new insight into the oxidative mechanism of caffeine and related methylxanthines in aprotic medium: May caffeine be really considered as an antioxidant? Biochim. Biophys. Acta, Gen. Subj., 2018, 1862(8), 17811789 .

http://dx.doi.org/10.1016/j.bbagen.2018.05.011 PMID: 29763642

[10] Savéant, J.M. Introduction: molecular and biomolecular electrochemistry. Chem. Rev., 2008, 108(7), 2111-2112.

http://dx.doi.org/10.1021/cr8004026 PMID: 18620363

[11] Yoshida, J.; Kataoka, K.; Horcajada, R.; Nagaki, A. Modern strategies in electroorganic synthesis. Chem. Rev., 2008, 108(7), 22652299.

http://dx.doi.org/10.1021/cr0680843 PMID: 18564879

[12] Petrucci, R.; Chiarotto, I.; Mattiello, L.; Passeri, D.; Rossi, M.; Zollo, G.; Feroci, A.M. Graphene Oxide: A Smart (Starting) Material for Natural Methylxanthines Adsorption and Detection. Molecules, 2019, 24(23), 4247.

http://dx.doi.org/10.3390/molecules24234247 PMID: 31766549

[13] Zuidema, J.; Merkus, F.W.H.M. Pharmacokinetics and pharmacodynamics of diprophylline. Pharm. Weekbl. Sci., 1981, 3, 13201325 .

http://dx.doi.org/10.1007/BF02193382

[14] Hasegawa, T.; Nadai, M.; Apichartpichean, R.; Muraoka, I.; Nabeshima, T.; Takagi, K. Pharmacokinetic characteristics of N7substituted theophylline derivatives and their interaction with quinolone in rats. J. Pharm. Sci., 1991, 80(10), 962-965. http://dx.doi.org/10.1002/jps.2600801012 PMID: 1664467

[15] Szczypka, M.; Lis, M.; Suszko-Pawłowska, A.; Pawlak, A.; Sysak, A.; Obmińska-Mrukowicz, B. Propentofylline, phosphodiesterase and adenosine reuptake inhibitor modulates lymphocyte subsets and lymphocyte activity after in-vivo administration in nonimmunized and SRBC-immunized mice. J. Pharm. Pharmacol., 2017, 69(9), 1166-1177.

http://dx.doi.org/10.1111/jphp.12760 PMID: 28620954

[16] Meskini, N.; Némoz, G.; Okyayuz-Baklouti, I.; Lagarde, M.; Prigent, A.F. Phosphodiesterase inhibitory profile of some related xanthine derivatives pharmacologically active on the peripheral microcirculation. Biochem. Pharmacol., 1994, 47(5), 781-788. http://dx.doi.org/10.1016/0006-2952(94)90477-4 PMID: 8135854

[17] Załuski, M.; Schabikowski, J.; Schlenk, M.; Olejarz-Maciej, A.; Kubas, B.; Karcz, T.; Kuder, K.; Latacz, G.; Zygmunt, M.; Synak, D.; Hinz, S.; Müller, C.E.; Kieć-Kononowicz, K. Novel multitarget directed ligands based on annelated xanthine scaffold with aromatic substituents acting on adenosine receptor and monoamine oxidase B. Synthesis, in vitro and in silico studies. Bioorg. Med. Chem., 2019, 27(7), 1195-1210.

http://dx.doi.org/10.1016/j.bmc.2019.02.004 PMID: 30808606
[18] Ito, K.; Caramori, G.; Lim, S.; Oates, T.; Chung, K.F.; Barnes, P.J.; Adcock, I.M. Expression and activity of histone deacetylases in human asthmatic airways. Am. J. Respir. Crit. Care Med., 2002, 166(3), 392-396.

http://dx.doi.org/10.1164/rccm.2110060 PMID: 12153977

[19] Hayallah, A.M.; Elgaher, W.A.; Salem, O.I.; Alim, A.A.; Alim, M.A. Design and synthesis of some new theophylline derivatives with bronchodilator and antibacterial activities. Arch. Pharm. Res., 2011, 34(1), 3-21.

http://dx.doi.org/10.1007/s12272-011-0101-8 PMID: 21468910

[20] Vignoli, J.A.; Bassoli, D.G.; Benassi, M.T. Antioxidant activity, polyphenols, caffeine and melanoidins in soluble coffee: the influence of processing conditions and raw material. Food Chem., 2011, $124,863-868$.

http://dx.doi.org/10.1016/j.foodchem.2010.07.008

[21] Yashin, A.; Yashin, Y.; Wang, J.Y.; Nemzer, B. Antioxidant and antiradical activity of coffee. Antioxidants, 2013, 2(4), 230-245.

http://dx.doi.org/10.3390/antiox2040230 PMID: 26784461

[22] Aleksandrova, K.; Belenichev, I.; Alexander, S.; Levich, S.; Yurchenko, D.; Buchtiyarova, N. Research of antioxidant properties of theophyllinyl-7-acetic acid derivatives. Med. Sci., 2014, 3, 187-194.

http://dx.doi.org/10.5455/oams.191214.or.078

[23] Hassan, I.; Dorjay, K.; Anwar, P. Pentoxifylline and its applications in dermatology. Indian Dermatol. Online J., 2014, 5(4), 510516.

http://dx.doi.org/10.4103/2229-5178.142528 PMID: 25396144

[24] Singh, N.; Kumar Shreshtha, A.; Thakur, M.S.; Patra, S. Xanthine scaffold: Scope and potential in drug development. Heliyon, 2018.4e00829

http://dx.doi.org/10.1016/j.heliyon.2018.e00829

[25] Müller, C.E.; Thorand, M.; Qurishi, R.; Diekmann, M.; Jacobson, K.A.; Padgett, W.L.; Daly, J.W. Imidazo[2,1-i]purin-5-ones and related tricyclic water-soluble purine derivatives: potent $\mathrm{A}(2 \mathrm{~A})$ - and A(3)-adenosine receptor antagonists. J. Med. Chem., 2002, 45(16), 3440-3450.

http://dx.doi.org/10.1021/jm011093d PMID: 12139454

[26] Shimada, J.; Kuroda, T.; Suzuki, F. A convenient synthesis of tricyclic purine derivatives. J. Heterocycl. Chem., 1993, 30, 241246.

http://dx.doi.org/10.1002/jhet.5570300141

[27] Drabczyńska, A.; Müller, C.E.; Karolak-Wojciechowska, J.; Schumacher, B.; Schiedel, A.; Yuzlenko, O.; Kieć-Kononowicz, K. N9benzyl-substituted 1,3-dimethyl- and 1,3-dipropyl-pyrimido[2,1f]purinediones: synthesis and structure-activity relationships at adenosine $\mathrm{A}_{1}$ and $\mathrm{A}_{2 \mathrm{~A}}$ receptors. Bioorg. Med. Chem., 2007, 15(14), 5003-5017.

http://dx.doi.org/10.1016/j.bmc.2007.04.018 PMID: 17499511

[28] Drabczyńska, A.; Müller, C.E.; Schiedel, A.; Schumacher, B.; Karolak-Wojciechowska, J.; Fruziński, A.; Zobnina, W.; Yuzlenko, O.; Kieć-Kononowicz, K. Phenylethyl-substituted pyrimido[2,1f]purinediones and related compounds: structure-activity relationships as adenosine $\mathrm{A}\left({ }_{1}\right)$ and $\mathrm{A}(2 \mathrm{~A})$ receptor ligands. Bioorg. Med. Chem., 2007, 15(22), 6956-6974.

http://dx.doi.org/10.1016/j.bmc.2007.07.051 PMID: 17827019

[29] Zygmunt, M.; Sapa, J.; Drabczyńska, A.; Karcz, T.; Müller, C.; Köse, M.; Latacz, G.; Schabikowski, J.; Bednarski, M.; KiećKononowicz, K. Synthesis and Analgesic Activity of Annelated Xanthine Derivatives in Experimental Models in Rodents. Arch. Pharm. (Weinheim), 2015, 348(10), 704-714. http://dx.doi.org/10.1002/ardp.201500169 PMID: 26248713

[30] Drabczyńska, A.; Schumacher, B.; Müller, C.E.; KarolakWojciechowska, J.; Michalak, B.; Pękala, E.; Kieć-Kononowicz, K. Impact of the aryl substituent kind and distance from pyrimido[2,1f]purindiones on the adenosine receptor selectivity and antagonistic properties. Eur. J. Med. Chem., 2003, 38(4), 397-402. http://dx.doi.org/10.1016/S0223-5234(03)00051-5 PMID: 12750027

[31] Baraldi, P.G.; Preti, D.; Tabrizi, M.A.; Fruttarolo, F.; Romagnoli, R.; Zaid, N.A.; Moorman, A.R.; Merighi, S.; Varani, K.; Borea, P.A. New pyrrolo[2,1-f]purine-2,4-dione and imidazo[2,1-f]purine2,4-dione derivatives as potent and selective human $\mathrm{A}_{3}$ adenosine receptor antagonists. J. Med. Chem., 2005, 48(14), 4697-4701. http://dx.doi.org/10.1021/jm058008c PMID: 16000006 
[32] Drabczyńska, A.; Yuzlenko, O.; Köse, M.; Paskaleva, M.; Schiedel, A.C.; Karolak-Wojciechowska, J.; Handzlik, J.; Karcz, T.; Kuder, K.; Müller, C.E.; Kieć-Kononowicz, K. Synthesis and biological activity of tricyclic cycloalkylimidazo-, pyrimido- and diazepinopurinediones. Eur. J. Med. Chem., 2011, 46(9), 3590-3607. http://dx.doi.org/10.1016/j.ejmech.2011.05.023 PMID: 21664729

[33] Drabczyńska, A.; Müller, C.E.; Lacher, S.K.; Schumacher, B.; Karolak-Wojciechowska, J.; Nasal, A.; Kawczak, P.; Yuzlenko, O.; Pękala, E.; Kieć-Kononowicz, K. Synthesis and biological activity of tricyclic aryloimidazo-, pyrimido-, and diazepinopurinediones. Bioorg. Med. Chem., 2006, 14(21), 7258-7281. http://dx.doi.org/10.1016/j.bmc.2006.06.052 PMID: 16844379

[34] Szymańska, E.; Drabczyńska, A.; Karcz, T.; Müller, C.E.; Köse, M.; Karolak-Wojciechowska, J.; Fruziński, A.; Schabikowski, J.; Doroz-Płonka, A.; Handzlik, J.; Kieć-Kononowicz, K. Similarities and differences in affinity and binding modes of tricyclic pyrimidoand pyrazinoxanthines at human and rat adenosine receptors. Bioorg. Med. Chem., 2016, 24(18), 4347-4362. http://dx.doi.org/10.1016/j.bmc.2016.07.028 PMID: 27485602

[35] Drabczyńska, A.; Karcz, T.; Szymańska, E.; Köse, M.; Müller, C.E.; Paskaleva, M.; Karolak-Wojciechowska, J.; Handzlik, J.; Yuzlenko, O.; Kieć-Kononowicz, K. Synthesis, biological activity and molecular modelling studies of tricyclic alkylimidazo-, pyrimidoand diazepinopurinediones. Purinergic Signal., 2013, 9(3), 395414 .

http://dx.doi.org/10.1007/s11302-013-9358-3 PMID: 23543220

[36] Koch, P.; Akkari, R.; Brunschweiger, A.; Borrmann, T.; Schlenk, M.; Küppers, P.; Köse, M.; Radjainia, H.; Hockemeyer, J.; Drabczyńska, A.; Kieć-Kononowicz, K.; Müller, C.E. 1,3-Dialkylsubstituted tetrahydropyrimido[1,2-f]purine-2,4-diones as multiple target drugs for the potential treatment of neurodegenerative diseases. Bioorg. Med. Chem., 2013, 21(23), 7435-7452.

http://dx.doi.org/10.1016/j.bmc.2013.09.044 PMID: 24139167

[37] Załuski, M.; Stanuch, K.; Karcz, T.; Hinz, S.; Latacz, G.; Szymańska, E.; Schabikowski, J.; Doroż-Płonka, A.; Handzlik, J.; Drabczyńska, A.; Müller, C.E.; Kieć-Kononowicz, K. Tricyclic xanthine derivatives containing a basic substituent: adenosine receptor affinity and drug-related properties. MedChemComm, $\mathbf{2 0 1 8 ,}$ 9(6), 951-962.

http://dx.doi.org/10.1039/C8MD00070K PMID: 30108984

[38] Wolfgang, A. Herrmann, Kocher, C. N-Heterocyclic Carbenes. Angew. Chem. Int. Ed. Engl., 1997, 36, 2162-2187.

http://dx.doi.org/10.1002/anie.199721621

[39] Marion, N.; Díez-González, S.; Nolan, S.P. N-heterocyclic carbenes as organocatalysts. Angew. Chem. Int. Ed. Engl., 2007, 46(17), 2988-3000.

http://dx.doi.org/10.1002/anie.200603380 PMID: 17348057

[40] Chiarotto, I.; Feroci, M.; Orsini, M.; Sotgiu, G.; Inesi, A. Electrogenerated N-heterocyclic carbenes: N-functionalization of benzoxazolones. Tetrahedron, 2009, 65, 3704-3710.

http://dx.doi.org/10.1016/j.tet.2009.02.057

[41] Glorius, F. N-Heterocyclic Carbenes in Transition Metal Catalysis. Topics in Organometallic Chemistry Series; Springer-Verlag Berlin Heidelberg, 2007.

http://dx.doi.org/10.1007/978-3-540-36930-1

[42] Scattolin, T.; Canovese, L.; Visentin, F.; Paganelli, S.; Canton, P.; Demitri, N. Synthesis of novel allyl palladium complexes bearing purine based NHC and a water soluble phosphine and their catalytic activity in the Suzuki-Miyaura coupling in water. Appl. Organomet. Chem., 2017, 20, 4034-4044. http://dx.doi.org/10.1002/aoc.4034

[43] Patrushev, S.S.; Rybalova, T.V.; Ivanov, I.D.; Vavilin, V.A.; Shults, E.E. Synthesis of a new class of bisheterocycles via the Heck reaction of eudesmane type methylene lactones with 8bromoxanthines. Tetrahedron, 2017, 73, 2717-2726.

http://dx.doi.org/10.1016/j.tet.2017.03.016

[44] Hu, J.J.; Bai, S.Q.; Yeh, H.H.; Young, D.J.; Chi, Y.; Hor, T.S.A. Nheterocyclic carbene $\mathrm{Pt}(\mathrm{II})$ complexes from caffeine: synthesis, structures and photoluminescent properties. Dalton Trans., 2011, 40(17), 4402-4406.

http://dx.doi.org/10.1039/c0dt01380c PMID: 21409198

[45] Valdés, H.; Canseco-González, D.; Germán-Acacio, J.M.; MoralesMorales, D. Xanthine based N-heterocyclic carbene (NHC) complexes. J. Organomet. Chem., 2018, 867, 51-54. http://dx.doi.org/10.1016/j.jorganchem.2018.01.008

[46] Schütz, J.; Herrmann, W.A. Purine-based carbenes at rhodium and iridium. J. Organomet. Chem., 2004, 689, 2995-2999. http://dx.doi.org/10.1016/j.jorganchem.2004.06.037

[47] Kascatan-Nebioglu, A.; Melaiye, A.; Hindi, K.; Durmus, S.; Panzner, M.J.; Hogue, L.A.; Mallett, R.J.; Hovis, C.E.; Coughenour, M.; Crosby, S.D.; Milsted, A.; Ely, D.L.; Tessier, C.A.; Cannon, C.L.; Youngs, W.J. Synthesis from caffeine of a mixed N-heterocyclic carbene-silver acetate complex active against resistant respiratory pathogens. J. Med. Chem., 2006, 49(23), 68116818.

http://dx.doi.org/10.1021/jm060711t PMID: 17154511

[48] Aher, S.B.; Muskawar, P.N.; Thenmozhi, K.; Bhagat, P.R. Recent developments of metal N-heterocyclic carbenes as anticancer agents. Eur. J. Med. Chem., 2014, 81, 408-419.

http://dx.doi.org/10.1016/j.ejmech.2014.05.036 PMID: 24858545

[49] Oehninger, L.; Rubbiani, R.; Ott, I. N-Heterocyclic carbene metal complexes in medicinal chemistry. Dalton Trans., 2013, 42(10), 3269-3284.

http://dx.doi.org/10.1039/C2DT32617E PMID: 23223752

[50] Liu, W.; Gust, R. Metal N-heterocyclic carbene complexes as potential antitumor metallodrugs. Chem. Soc. Rev., 2013, 42(2), 755773 .

http://dx.doi.org/10.1039/C2CS35314H PMID: 23147001

[51] Bertrand, B.; Stefan, L.; Pirrotta, M.; Monchaud, D.; Bodio, E.; Richard, P.; Le Gendre, P.; Warmerdam, E.; de Jager, M.H.; Groothuis, G.M.M.; Picquet, M.; Casini, A. Caffeine-based gold(I) $\mathrm{N}$-heterocyclic carbenes as possible anticancer agents: synthesis and biological properties. Inorg. Chem., 2014, 53(4), 2296-2303. http://dx.doi.org/10.1021/ic403011h PMID: 24499428

[52] Baker, M.V.; Barnard, P.J.; Berners-Price, S.J.; Brayshaw, S.K.; Hickey, J.L.; Skelton, B.W.; White, A.H. Synthesis and structural characterisation of linear $\mathrm{Au}(\mathrm{I}) \mathrm{N}$-heterocyclic carbene complexes: New analogues of the Au(I) phosphine drug Auranofin. J. Organomet. Chem., 2005, 690, 5625-5635.

http://dx.doi.org/10.1016/j.jorganchem.2005.07.013

[53] Wang, H.M.J. Lin. I.J.B. Facile Synthesis of Silver(I)-Carbene Complexes. Useful Carbene Transfer Agents. Organometallics, 1998, 17, 972-975.

http://dx.doi.org/10.1021/om9709704

[54] Rubbiani, R.; Kitanovic, I.; Alborzinia, H.; Can, S.; Kitanovic, A.; Onambele, L.A.; Stefanopoulou, M.; Geldmacher, Y.; Sheldrick, W.S.; Wolber, G.; Prokop, A.; Wölfl, S.; Ott, I. Benzimidazol-2ylidene gold(I) complexes are thioredoxin reductase inhibitors with multiple antitumor properties. J. Med. Chem., 2010, 53(24), 86088618.

http://dx.doi.org/10.1021/jm100801e PMID: 21082862

[55] Brackemeyer, D.; Hervé, A. Schulte to Brinke, C.; Jahnke, M.C., Hahn, F.E. A Versatile Methodology for the Regioselective C8Metalation of Purine Bases. J. Am. Chem. Soc., 2014, 136, 78417844.

http://dx.doi.org/10.1021/ja5030904 PMID: 24823250

[56] Landaeta, V.R.; Rodríguez-Lugo, R.E.; Rodríguez-Arias, E.N.; Coll-Gómez, D.S.; González, T. Studies on the coordination chemistry of methylated xanthines and their imidazolium salts. Part 1: benzyl derivatives. Transition. Met. Chem., 2010, 35, 165-175. http://dx.doi.org/10.1007/s11243-009-9310-0

[57] Szadkowska, A.; Staszko, S.; Zaorska, E.; Pawłowski, R. A theophylline based copper N-heterocyclic carbene complex: synthesis and activity studies in green media. RSC Advances, 2016, 6, 4424844253.

http://dx.doi.org/10.1039/C6RA06682H

[58] Traube, W. Der synthetische Aufbau der Harnsäure, des Xanthins, Theobromins, Theophyllins und Caffeïns aus der Cyanessigsäure. Ber. Deut. Chem. Ges., 1900, 33, 3035-3056.

http://dx.doi.org/10.1002/cber.19000330352

[59] Lister, J.H. The Purines, Supplement 1.The Chemistry of Heterocyclic Compounds; Taylor, E.C.; Weissberger, A., Eds.; John Wiley: New York, 1996, Vol. 54, http://dx.doi.org/10.1002/9780470187944

[60] Vishnyakova, T.P.; Golubeva, I.A.; Glebova, E.V. Substituted Ureas. Methods of Synthesis and Applications. Russ. Chem. Rev., 1985, 54, 429-449.

http://dx.doi.org/10.1070/RC1985v054n03ABEH003022 
[61] Hutzenlaub, W.; Pfleiderer, W. Purine, XIII Vereinfachte Synthesen für 7-Methyl- und 1,7-Dimethyl-xanthin und -harnsäure. Liebigs Ann. Chem., 1979, 1847-1854.

http://dx.doi.org/10.1002/jlac.197919791122

[62] Müller, C.E.; Shi, D.; Manning, M., Jr; Daly, J.W. Synthesis of paraxanthine analogs (1,7-disubstituted xanthines) and other xanthines unsubstituted at the 3-position: structure-activity relationships at adenosine receptors. J. Med. Chem., 1993, 36(22), 33413349. http://dx.doi.org/10.1021/jm00074a015 PMID: 8230124

[63] Muller, C.E.; Sandoval-amirez, J. A New Versatile Synthesis of Xanthines with Variable Substituents in the 1-, 3-, 7- and 8Positions. Synthesis, 1995, 1295-1299.

http://dx.doi.org/10.1055/s-1995-4082

[64] Weyler, S.; Hayallah, A.M.; Muller, C.E. Versatile, convenient synthesis of pyrimido[1,2,3-cd] purinediones. Tetrahedron, 2003, 59, 47-54.

http://dx.doi.org/10.1016/S0040-4020(02)01485-0

[65] Herr, R.J.; Vogt, P.F.; Meckler, H.; Trova, M.P.; Schow, S.R.; Petter, R.C. Preparation of 8-substituted xanthine CVT-124 precursor by late stage pyrimidine ring closure. J. Org. Chem., 2002, 67(1), 188-193.

http://dx.doi.org/10.1021/jo015925r PMID: 11777458

[66] Bridson, P.K.; Wang, X. 1-Substituent Xanthines. Synthesis, 1995, 7, 855-858.

http://dx.doi.org/10.1055/s-1995-4017

[67] Hergueta, A.R.; Figueira, M.J.; López, C.; Caamaño, O.; Fernández, F.; Rodríguez-Borges, J.E. Synthesis of series of 1- and 3differently substituted xanthines from imidazoles. Chem. Pharm. Bull. (Tokyo), 2002, 50(10), 1379-1382. http://dx.doi.org/10.1248/cpb.50.1379 PMID: 12372868

[68] Itaya, T.; Ogawa, K. Synthesis of 3,9-dialkylguanines and 3methylguanosine, a key intermediate for the synthesis of Y nucleosides. Tetrahedron Lett., 1978, 32, 2907-2910.

http://dx.doi.org/10.1016/S0040-4039(01)94895-6

[69] Zavialov, I.A.; Dahanukar, V.H.; Nguyen, H.; Orr, C.; Zhang, F.; Andrews, D.R. New and practical method for synthesis of 1- and 1,3-substituted xanthines. Org. Lett., 2004, 6(13), 2237-2240. http://dx.doi.org/10.1021/o1049272n PMID: 15200329

[70] Shamim, M.T.; Ukena, D.; Padgett, W.L.; Daly, J.W. Effects of 8phenyl and 8-cycloalkyl substituents on the activity of mono-, di-, and trisubstituted alkylxanthines with substitution at the 1-, 3-, and 7-positions. J. Med. Chem., 1989, 32(6), 1231-1237. http://dx.doi.org/10.1021/jm00126a014 PMID: 2724296

[71] Ruddarraju, R.R.; Murugulla, A.C.; Kotla, R.; Chandra Babu Tirumalasetty, M.; Wudayagiri, R.; Donthabakthuni, S.; Maroju, R.; Baburao, K.; Parasa, L.S. Design, synthesis, anticancer, antimicrobial activities and molecular docking studies of theophylline containing acetylenes and theophylline containing 1,2,3-triazoles with variant nucleoside derivatives. Eur. J. Med. Chem., 2016, 123, 379-396.

http://dx.doi.org/10.1016/j.ejmech.2016.07.024 PMID: 27487568

[72] Constantin, S.; Lupascu, F.G.; Apotrosoaei, M.; Vasincu, I.M.; Lupascu, D.; Buron, F.; Routier, S.; Profire, L. Synthesis and biological evaluation of the new 1,3-dimethylxanthine derivatives with thiazolidine-4-one scaffold. Chem. Cent. J., 2017, 11, 12-25. http://dx.doi.org/10.1186/s13065-017-0241-0 PMID: 28203273

[73] Constantin, S.; Buron, F.; Routier, S.; Confederat, L.; Iacob, A.T.; Miron, A.; Profire, L. Studies On Xanthine Derivatives (II). Synthesis And Antioxidant Effects Of Some Hydrazones With Xanthine Structure. Farmacia, 2016, 64, 565-571.

[74] Lupascu, F.G.; Giusca, S.E.; Caruntu, I.D.; Anton, A.; Lupușoru, C.E.; Profire, L. The safety profile of new antidiabetic xanthine derivatives and their chitosan based formulations. Eur. J. Pharm. Sci., 2019, 127, 71-78.

http://dx.doi.org/10.1016/j.ejps.2018.10.015 PMID: 30339870

[75] Soltani Rad, M.N.; Behrouz, S.; Abdo-Reza Nekoei, A.R. 18tBromocaffeine (8-BC): A New Versatile Reagent for Conversion of Aldoximes into Nitriles. Synlett, 2012, 23, 1191-1198. http://dx.doi.org/10.1055/s-0031-129036

[76] Xi, P.; Yang, F.; Qin, S.; Zhao, D.; Lan, J.; Gao, G.; Hu, C.; You, J. Palladium(II)-catalyzed oxidative $\mathrm{C}-\mathrm{H} / \mathrm{C}-\mathrm{H}$ cross-coupling of heteroarenes. J. Am. Chem. Soc., 2010, 132(6), 1822-1824. http://dx.doi.org/10.1021/ja909807f PMID: 20102197
[77] van den Berg, D.; Zoellner, K.R.; Ogunrombi, M.O.; Malan, S.F.; Terre'Blanche, G.; Castagnoli, N., Jr; Bergh, J.J.; Petzer, J.P. Inhibition of monoamine oxidase B by selected benzimidazole and caffeine analogues. Bioorg. Med. Chem., 2007, 15(11), 3692-3702. http://dx.doi.org/10.1016/j.bmc.2007.03.046 PMID: 17416530

[78] Huang, Y.; Song, F.; Wang, Z.; Xi, P.; Wu, N.; Wang, Z.; Lan, J.; You, J. Dehydrogenative Heck coupling of biologically relevant Nheteroarenes with alkenes: discovery of fluorescent core frameworks. Chem. Commun. (Camb.), 2012, 48(23), 2864-2866. http://dx.doi.org/10.1039/c2cc17557f PMID: 22302073

[79] Ma, Q.S.; Yao, Y.; Zheng, Y.C.; Feng, S.; Chang, J.; Yu, B.; Liu, H.M. Ligand-based design, synthesis and biological evaluation of xanthine derivatives as LSD1/KDM1A inhibitors. Eur. J. Med. Chem., 2019, 162, 555-567.

http://dx.doi.org/10.1016/j.ejmech.2018.11.035 PMID: 30472603

[80] Kim, D.; Jun, H.; Lee, H.; Hong, S.S.; Hong, S. Development of new fluorescent xanthines as kinase inhibitors. Org. Lett., 2010, 12(6), 1212-1215.

http://dx.doi.org/10.1021/ol100011n PMID: 20184370

[81] Makhloufi, A.; Frank, W.; Ganter, C. Converting Caffeine to Electronically Different $\mathrm{N}-\mathrm{Heterocyclic}$ Carbenes with a Hypoxanthine Backbone. Organomet., 2012, 31, 7272-7277.

http://dx.doi.org/10.1021/om300836w

[82] Martins, I.L.; Miranda, J.P.; Oliveira, N.G.; Fernandes, A.S.; Gonçalves, S.; Antunes, A.M.M. Synthesis and biological activity of 6 selenocaffeine: potential modulator of chemotherapeutic drugs in breast cancer cells. Molecules, 2013, 18(5), 5251-5264.

http://dx.doi.org/10.3390/molecules18055251 PMID: 23698041

[83] Pandolfi, F.; Chiarotto, I.; Mattiello, L.; Rocco, D.; Feroci, M. Cathodic reduction of caffeine: amino-functionalized imidazole from a bio-based reagent. Synlett, 2019, 30, 1215-1218. http://dx.doi.org/10.1055/s-0037-1611483

[84] Pandolfi, F.; Mattiello, L.; Zane, D.; Feroci, M. Electrochemical behaviour of 9-methylcaffeinium iodide and in situ electrochemical synthesis of hymeniacidin. Electrochim. Acta, 2018, 280, 71-76. http://dx.doi.org/10.1016/j.electacta.2018.05.073

[85] Monteiro, J.; Alves, M.G.; Oliveira, P.F.; Silva, B.M. Pharmacological potential of methylxanthines: Retrospective analysis and future expectations. Crit. Rev. Food Sci. Nutr., 2019, 59(16), 25972625.

http://dx.doi.org/10.1080/10408398.2018.1461607 PMID: 29624433

[86] Devasagayam, T.P.A.; Kamat, J.P.; Mohan, H.; Kesavan, P.C. Caffeine as an antioxidant: inhibition of lipid peroxidation induced by reactive oxygen species. Biochim. Biophys. Acta, 1996, 1282(1), 63-70.

http://dx.doi.org/10.1016/0005-2736(96)00040-5 PMID: 8679661

[87] Prasanthi, J.R.P.; Dasari, B.; Marwarha, G.; Larson, T.; Chen, X.; Geiger, J.D.; Ghribi, O. Caffeine protects against oxidative stress and Alzheimer's disease-like pathology in rabbit hippocampus induced by cholesterol-enriched diet. Free Radic. Biol. Med., 2010, 49(7), 1212-1220.

http://dx.doi.org/10.1016/j.freeradbiomed.2010.07.007 PMID: 20638472

[88] Varma, S.D.; Hegde, K.R. Kynurenine-induced photo oxidative damage to lens in vitro: protective effect of caffeine. Mol. Cell. Biochem., 2010, 340(1-2), 49-54.

http://dx.doi.org/10.1007/s11010-010-0399-4 PMID: 20204679

[89] León-Carmona, J.R.; Galano, A. Is caffeine a good scavenger of oxygenated free radicals? J. Phys. Chem. B, 2011, 115(15), 45384546.

http://dx.doi.org/10.1021/jp201383y PMID: 21438616

[90] Brezová, V.; Šlebodová, A.; Staško, A. Coffee as a source of antioxidants: an EPR study. Food Chem., 2009, 114, 859-868.

http://dx.doi.org/10.1016/j.foodchem.2008.10.025

[91] Tirzitis, G.; Bartosz, G. Determination of antiradical and antioxidant activity: basic principles and new insights. Acta Biochim. Pol., 2010, 57(2), 139-142.

http://dx.doi.org/10.18388/abp.2010_2386 PMID: 20454707

[92] Hansen, B.H.; Dryhurst, G. Electrochemical oxidation of theobromine and caffeine at the pyrolitic graphite electrode. Electroanal. Chem. Interfacial Electrochem., 1971, 30, 407-416. http://dx.doi.org/10.1016/0368-1874(71)87024-7 
[93] Hansen, B.H.; Dryhurst, G. Electrochemical oxidation of thephylline at the pyrolitic graphite electrode. Electroanal. Chem. Interfacial Electrochem., 1971, 32, 405-414.

http://dx.doi.org/10.1016/S0022-0728(71)80143-2

[94] Hansen, B.H.; Dryhurst, G. Voltammetric oxidation of some biologically important xanthines at the pyrolitic graphite electrode. Electroanal. Chem. Interfacial Electrochem., 1971, 30, 417-426. http://dx.doi.org/10.1016/0368-1874(71)87025-9

[95] Quintanilla, G.; Usarralde, A.; Pérez, I.; Gargiulo, M.L.; Yakupoglu, G.; Martin, A.; Barba, F. Anodic oxidation of caffeine and theophylline in glacial acetic acid. Org. Supramol. Chem., 2016, 3, 414-416. http://dx.doi.org/10.1002/slct.201500047

[96] Chan, K.K.; Ganguly, R.; Li, Y.; Richard, D.; Webster, R.D. Electrochemically Controlled One-Electron Oxidation Coupled to Con- secutive Hydrogen Atom Transfer of Caffeine. ChemElectroChem, 2014, $1,1557-1562$.

http://dx.doi.org/10.1002/celc.201402203

[97] Chiarotto, I.; Mattiello, L.; Pandolfi, F.; Rocco, D.; Marta Feroci, M.; Petrucci, R. Electrochemical Oxidation of Theophylline in Organic Solvents: HPLC-PDA-ESI-MS/MS Analysis of the Oxidation Products. ChemElectroChem, 2019, 6, 4511-4521. http://dx.doi.org/10.1002/celc.201901071

[98] Trani, A.; Petrucci, R.; Marrosu, G.; Zane, D.; Curulli, A. Selective electrochemical determination of caffeine at a gold-chitosan nanocomposite sensor: May little change on nanocomposites synthesis affect selectivity? J. Electroanal. Chem., 2017, 788, 99-106. http://dx.doi.org/10.1016/j.jelechem.2017.01.049

DISCLAIMER: The above article has been published in Epub (ahead of print) on the basis of the materials provided by the author. The Editorial Department reserves the right to make minor modifications for further improvement of the manuscript. 